\title{
Looking at Flavonoid Biodiversity in Horticultural Crops: A Colored Mine with Nutritional Benefits
}

\author{
Aurelia Scarano ${ }^{1}\left(\mathbb{D}\right.$, Marcello Chieppa ${ }^{2}\left(\mathbb{D}\right.$ and Angelo Santino ${ }^{1, *(\mathbb{C}}$ \\ 1 ISPA-CNR, Institute of Science of Food Production, C.N.R. Unit of Lecce, 73100 Lecce, Italy; \\ aurelia.scarano@ispa.cnr.it \\ 2 National Institute of Gastroenterology 'S. De Bellis', Institute of Research, 70013 Castellana Grotte (Ba), Italy; \\ mchieppa@yahoo.it \\ * Correspondence: angelo.santino@ispa.cnr.it
}

Received: 8 October 2018; Accepted: 5 November 2018; Published: 7 November 2018

\begin{abstract}
Flavonoids represent a wide group of plant secondary metabolites implicated in many physiological roles, from the attraction of pollinators to the protection against biotic or abiotic stresses. Flavonoids are synthetized in a number of horticultural crops that are important components of our daily diet. In the last decades, the consumption of vegetables rich in antioxidants has been strongly promoted from the perspective of prevention/protection against chronic diseases. Therefore, due to their nutritional importance, several attempts have been made to enhance flavonoid levels in species of agronomic interest. In this review, we focus on the flavonoid biodiversity among the major horticultural species, which is responsible of differences among closely related species and influences the qualitative/quantitative composition. We also review the role of flavonoids in the nutritional quality of plant products, contributing to their organoleptic and nutritional properties, and the main strategies of biofortification to increase their content.
\end{abstract}

Keywords: biodiversity; biofortification; flavonoids; horticultural crops; nutritional quality

\section{Introduction}

To date, more than 6000 different flavonoids have been reported among the species of the plant kingdom. Based on their chemical structure and modification, flavonoids have been classified into many subgroups, as chalcones, flavones, isoflavones, flavonols, anthocyanins, proanthocyanidins, flavanols, and aurones [1,2]. All these compounds are synthesized via the phenylpropanoid biosynthetic pathway starting from the common precursor, phenylalanine. The phenylpropanoid pathway can be divided in an early branch of biosynthesis, driven by enzymes responsible for the production of all the main precursors, and late branches of biosynthesis, which generate the downstream flow of flavonoids. The downstream and the lateral biosynthetic branches are important contributors of the great chemical diversity of these metabolites. A number of different enzymes, i.e., glycosyl/methyl transferases, isomerases, reductases, hydroxylases, and dioxygenases, are responsible of the main decorations of the final chemical structures of flavonoids. Despite some genetic variance in these reactions, the main skeleton of the flavonoid biosynthesis pathway is widely conserved in the plant kingdom. Each species synthesizes specific flavonoid subgroups, which constitutes a chemical signature expressing the biodiversity of these phytochemicals and the specialization acquired by each species during evolution.

The reasons explaining why flavonoids are strongly conserved along the plant kingdom lie mainly on their physiological functions. Their role as developmental regulators of auxin transport and catabolism and the protection against UV radiation are considered the most ancestral functions of these phytochemicals [3]. Other functions such as the attraction of pollinators, the interaction 
with the rhizosphere, and the protection against phytopathogens/predators have probably evolved later. Flavonoids and anthocyanins, often acting as co-pigments, are also main contributors to the beautiful colors of flowers and fruits and are important UV-B protectors in terms of their absorbance and antioxidant activities, reducing the possible consequences/damages triggered by ROS species in plant tissues. In fact, the expression of genes belonging to early flavonoid biosynthesis is often used as a marker of the UV-B photoreceptor pathway and acclimation response [4].

The chemical biodiversity of flavonoids reflects the metabolic plasticity of land plants and, as for other secondary metabolites, their adaptation to local conditions. The occurrence of flavonoids shows variation among different plant species, the genetic background, the geographical area, the developmental stage of the plant, and external factors, such as abiotic or biotic stresses. Human domestication has been another factor affecting the metabolic compositions in current horticultural crops and consequently their nutritional value.

\section{Natural Flavonoids Variation in Horticultural Species}

Table 1 and Figure 1 report the main flavonoids and their amounts detected in common horticultural crops. The qualitative/quantitative traits of flavonoid composition reflect species-specific steps of glycosylation, methylation, or other reactions which add other groups to the main backbone. The addition of glucose residues, or other sugars like arabinose or rhamnose, is a common modification step of flavonoids, together with acylation or even phenyl-acylation, producing very diverse and sophisticated compounds. Glycosylation of flavonoids is mediated by UDP-sugar-dependent glycosyltransferases (UGTs) that are active in the cytosol [5]. Glycosylation increases the solubility of flavonoids, important feature for storage inside vacuole or their transport to cell wall [6]. The great part of information on these processes derives from Arabidopsis, in which the flavonoid glycosylation has been well studied, and many glycosyltransferases have been identified and functionally characterized (i.e., flavonol 3-O-rhamnosyltransferase (F3RhaT, UGT78D1), flavonol 7-O-glucosyltransferase (F7GlcT, UGT73C6), a flavonoid 3-O-glucosyltransferase (F3GlcT, UGT78D2), flavonol 7-O-rhamnosyltransferase (F7RhaT, UGT89C1), flavonol 3-O-arabinosyltransferase (F3AraT, UGT78D3), flavonoid 3-O-glucoside 2"-O-glucosyltransferase (Fd3GGlcT, UGT79B6); 6 and references therein). Further information is available from purple potato and sweet potato in which UDP-glucose: flavonoid-3-O-glucosyltransferase have been as well characterized $[7,8]$.

Acylation is another frequent modification occurring on flavonoids and anthocyanins. Cyanidin or pelargonidin glycosides have been found acylated or double acylated with $p$-coumaroyl, sinapoyl, caffeoyl, feruloyl, or malonyl functionalities in broccoli sprouts [9], red radish [10], red cabbage [11] or purple sweet potato [12]. More than 20 different non-acylated flavonol glycosides and acylated mono-, di-, tri-, and tetra-glycosides of quercetin, kaempferol, and isorhamnetin have been found in Brassica rapa. Interestingly, isorhamnetin derivatives are abundant in B. rapa group, but are usually absent in B. oleracea [11], thus confirming the strict specificity of lateral chain decorations among closely related species.

Several enzymes involved in anthocyanin- and flavonoid modifications, namely anthocyanin-3$O$-glucosyltransferase (SIA3GlcT), anthocyanin-3-O-glucoside-6"-O-rhamnosyltransferase (SlA3Glc6" RhaT), anthocyanin-5-O-glucosyltransferase (SIA5GlcT), anthocyanin-3-O-rutinoside-4" $-O$-phenyltransferase, and flavonoid-3-O-rutinoside-4"-O-phenylacyltransferase (SIFd3Glc6" Rha4"PAT) have been identified in purple tomato [13]. This class of phenylacyl-transferases are also well conserved in Solanaceous species [13]. Some bibliographic sources suggest the presence of twenty-nine putative flavonol-phenylacylglycosides in Brassicaceae, even though the flavonol-phenylacyl glycosides found and annotated to date are only $2^{\prime \prime}$ - or $4^{\prime \prime}$-O-phenylacylated-flavonols [14]. However, phenylacyl-transferases are not commonly shared in flavonol biosynthesis pathway, indicating a more recent adaptation and a more selective restriction in their occurrence in some species [14]. In Arabidopsis, the phenylacylated flavonols have been related to the response of UV-B light tolerance [14], indicating their specialization to counteract this abiotic stress. 
Table 1. Flavonoid classes and content in horticultural crops. Types and amounts of flavonoid are reported either from the USDA database (USDA; https: / / www.ars.usda.gov/) [15] or from literature. USDA source refers specifically to flavonoid content evaluated by column chromatography or HPLC analyses and are expressed as mg/100 g FW of edible portion. The literature source refers to either HPLC or spectrophotometric quantifications, with the aim to provide further information on flavonoid amounts and the total flavonoid content in horticultural crops. TFC: total flavonoid content. NA: not available.

\begin{tabular}{|c|c|c|c|c|}
\hline Family & $\begin{array}{c}\text { Scientific Name/Common } \\
\text { Name }\end{array}$ & Class of Flavonoids & $\begin{array}{l}\text { Types and Content of Flavonoids } \\
\left(\mathrm{mg} \cdot 100 \mathrm{~g}^{-1} \mathrm{FW} \text {, from USDA) }\right.\end{array}$ & $\begin{array}{l}\text { Types and Content of Flavonoids } \\
\text { (Other Sources) }\end{array}$ \\
\hline \multirow[t]{6}{*}{ Brassicaceae } & $\begin{array}{l}\text { Brassica oleracea var. acefala / } \\
\text { Kale }\end{array}$ & Flavonols & $\begin{array}{c}\text { Isorhamnetin } 23.60 \\
\text { Kaempferol } 46.80 \\
\text { Quercetin } 22.58\end{array}$ & $\begin{array}{c}\text { Isorhamnetin } 60 \mathrm{mg} / \mathrm{Kg} \mathrm{FW} \\
\text { Kaempferol } 24 \mathrm{mg} / \mathrm{Kg} \mathrm{FW} \\
\text { Luteolin } 25 \mathrm{mg} / \mathrm{Kg} \mathrm{FW} \\
{[16]}\end{array}$ \\
\hline & $\begin{array}{c}\text { Brassica oleracea var. capitata/ } \\
\text { Cabbage }\end{array}$ & $\begin{array}{l}\text { Flavonols } \\
\text { Flavones }\end{array}$ & $\begin{array}{l}\text { Quercetin, } 0.28 \\
\text { Kaempferol, } 0.18 \\
\text { Luteolin, } 0.10 \\
\text { Apigenin, } 0.02\end{array}$ & $\begin{array}{c}\text { TFC } 40 \mathrm{mg} \text { QE } / \mathrm{g} \text { FW } \\
\text { Kaempferol } 31 \mathrm{mg} / \mathrm{Kg} \mathrm{FW} \\
\text { Luteolin } 33 \mathrm{mg} / \mathrm{Kg} \mathrm{FW} \\
{[16,17]}\end{array}$ \\
\hline & $\begin{array}{c}\text { Brassica oleracea var. capitata } \mathrm{f} . \\
\text { rubra/ } \\
\text { Red Cabbage }\end{array}$ & $\begin{array}{c}\text { Flavonols } \\
\text { Flavones } \\
\text { Anthocyanins }\end{array}$ & $\begin{array}{c}\text { Quercetin, } 0.36 \\
\text { Myricetin, } 0.20 \\
\text { Luteolin, } 0.10 \\
\text { Apigenin, } 0.06 \\
\text { Cyanidin, 209.83 } \\
\text { Delphinidin, } 0.10 \\
\text { Pelargonidin, } 0.02\end{array}$ & $\begin{array}{c}\text { TFC } 842 \mathrm{mg} \mathrm{CE} / \mathrm{Kg} \mathrm{FW} \\
\text { TFC } 74 \mathrm{mg} \text { QE } / \mathrm{g} \mathrm{FW} \\
\text { Cyanidin } 40-750 \mathrm{mg} / \mathrm{Kg} \mathrm{FW} \\
{[17-19]}\end{array}$ \\
\hline & $\begin{array}{l}\text { Brassica rapa var. Pekinensis/ } \\
\text { Chinese cabbage }\end{array}$ & Flavonols & Kaempferol, 22.51 & $\begin{array}{c}\text { TFC } 57 \mathrm{mg} \mathrm{QE} / \mathrm{g} \mathrm{FW} \\
\text { Kaempferol } 33 \mathrm{mg} / \mathrm{Kg} \mathrm{FW} \\
\text { Isorhamnetin } 46 \mathrm{mg} / \mathrm{Kg} \mathrm{FW} \\
{[16,17]}\end{array}$ \\
\hline & $\begin{array}{c}\text { Brassica oleracea var. botrytis } \\
\text { Cauliflower }\end{array}$ & $\begin{array}{c}\text { Flavonols } \\
\text { Flavones }\end{array}$ & $\begin{array}{l}\text { Quercetin, } 0.54 \\
\text { Kaempferol, } 0.36 \\
\text { Luteolin, } 0.09 \\
\text { Apigenin, } 0.03\end{array}$ & $\begin{array}{c}\text { TFC } 267.21 \mathrm{mg} \mathrm{CE} / 100 \mathrm{~g} \text { DW } \\
\text { Isorhamnetin } 40 \mathrm{mg} / \mathrm{Kg} \mathrm{FW} \\
\text { Kaempferol } 7 \mathrm{mg} / \mathrm{Kg} \mathrm{FW} \\
\text { Quercetin } 2 \mathrm{mg} / \mathrm{Kg} \mathrm{FW} \\
\text { Luteolin } 13 \mathrm{mg} / \mathrm{Kg} \mathrm{FW} \\
\text { Apigenin } 5 \mathrm{mg} / \mathrm{Kg} \mathrm{FW} \\
{[16,20]}\end{array}$ \\
\hline & $\begin{array}{l}\text { Brassica rapa/ } \\
\text { Turnip }\end{array}$ & Flavonols & $\begin{array}{l}\text { Kaempferol, } 11.87 \\
\text { Quercetin, } 0.73\end{array}$ & $\begin{array}{l}\text { Isorhamnetin glycosides } 2-5 \mathrm{mg} / \mathrm{Kg} \mathrm{DW} \\
\text { (stem/leaves) } \\
\text { Isorhamnetin glycosides } 6.5 \mathrm{mg} / \mathrm{Kg} \mathrm{DW} \\
\text { (flower buds) } \\
{[21]}\end{array}$ \\
\hline
\end{tabular}


Table 1. Cont

\begin{tabular}{|c|c|c|c|c|}
\hline Family & $\begin{array}{l}\text { Scientific Name/Common } \\
\text { Name }\end{array}$ & Class of Flavonoids & $\begin{array}{l}\text { Types and Content of Flavonoids } \\
\left(\mathrm{mg} \cdot 100 \mathrm{~g}^{-1} \mathrm{FW} \text {, from USDA) }\right.\end{array}$ & $\begin{array}{l}\text { Types and Content of Flavonoids } \\
\text { (Other Sources) }\end{array}$ \\
\hline & $\begin{array}{l}\text { Raphanus sativus/ } \\
\text { Radish }\end{array}$ & $\begin{array}{l}\text { Flavonols } \\
\text { Anthocyanins }\end{array}$ & $\begin{array}{l}\text { Kaempferol, } 0.86 \\
\text { Pelargonidin, } 63.13\end{array}$ & $\begin{array}{c}\text { TFC } 179 \text { mg CE /Kg FW } \\
\text { TFC 60-96 mg/g DW } \\
\text { Pelargonidin glycosides } 1.80 \mathrm{mg} / \mathrm{g} \mathrm{DW} \\
\text { Kaempferol } 4 \mathrm{mg} / \mathrm{Kg} \mathrm{FW} \\
{[16,18,22]}\end{array}$ \\
\hline & $\begin{array}{c}\text { Brassica oleracea var. italica/ } \\
\text { Broccoli }\end{array}$ & $\begin{array}{l}\text { Flavonols } \\
\text { Flavones }\end{array}$ & $\begin{array}{c}\text { Kaempferol, } 7.84 \\
\text { Quercetin, } 3.26 \\
\text { Luteolin, } 0.80 \\
\text { Myricetin, } 0.06\end{array}$ & $\begin{array}{c}\text { Kaempferol } 21 \mathrm{mg} / \mathrm{Kg} \mathrm{FW} \\
\text { Quercetin } 5 \mathrm{mg} / \mathrm{Kg} \mathrm{FW} \\
\text { Quercetin } 0.03-10.85 \mathrm{mg} / 100 \mathrm{~g} \mathrm{FW} \\
\text { Kaempferol } 0.24-13.20 \mathrm{mg} / 100 \mathrm{~g} \mathrm{FW} \\
{[16,23]}\end{array}$ \\
\hline \multirow[t]{2}{*}{ Liliaceae } & $\begin{array}{l}\text { Allium cepa/ } \\
\text { Onion }\end{array}$ & $\begin{array}{l}\text { Flavonols } \\
\text { Flavones }\end{array}$ & $\begin{array}{l}\text { Quercetin, 20.30 } \\
\text { Isorhamnetin, 5.01 } \\
\text { Kaempferol, 0.65 } \\
\text { Myricetin, 0.03 }\end{array}$ & $\begin{array}{c}\text { TFC } 270-1187 \mathrm{mg} / \mathrm{Kg} \mathrm{FW} \\
\text { TFC } 170 \mathrm{mg} \text { CE } / \mathrm{Kg} \text { FW } \\
\text { (mostly quecetin, kaempferol and } \\
\text { isorhamnetin derivatives) } \\
\text { Kaemfperol } 41 \mathrm{mg} / \mathrm{Kg} \mathrm{FW} \\
\text { Quercetin } 14 \mathrm{mg} / \mathrm{Kg} \mathrm{DW} \\
\text { Apigenin } 26 \mathrm{mg} / \mathrm{Kg} \mathrm{FW} \\
{[16,18,24]}\end{array}$ \\
\hline & $\begin{array}{l}\text { Allium ampeloprasum/ } \\
\text { Leek }\end{array}$ & $\begin{array}{l}\text { Flavonols } \\
\text { Flavones }\end{array}$ & $\begin{array}{l}\text { Kaempferol, } 2.67 \\
\text { Myricetin, } 0.22 \\
\text { Quercetin, } 0.09\end{array}$ & $\begin{array}{c}\text { Quercetin } 1.56 \mathrm{mg} / \mathrm{g} \mathrm{DW} \\
\text { Rutin } 1.04 \mathrm{mg} / \mathrm{g} \text { DW } \\
\text { Kaempferol } 118 \mathrm{mg} / \mathrm{Kg} \mathrm{DW} \\
\text { Quercetin } 9 \mathrm{mg} / \mathrm{KG} \mathrm{FW} \\
\text { Luteolin } 33 \mathrm{mg} / \mathrm{Kg} \mathrm{FW} \\
{[16,25]}\end{array}$ \\
\hline
\end{tabular}


Table 1. Cont

\begin{tabular}{|c|c|c|c|c|}
\hline Family & $\begin{array}{c}\text { Scientific Name/Common } \\
\text { Name }\end{array}$ & Class of Flavonoids & $\begin{array}{l}\text { Types and Content of Flavonoids } \\
\left(\mathrm{mg} \cdot 100 \mathrm{~g}^{-1} \mathrm{FW} \text {, from USDA) }\right.\end{array}$ & $\begin{array}{c}\text { Types and Content of Flavonoids } \\
\text { (Other Sources) }\end{array}$ \\
\hline & $\begin{array}{l}\text { Allium sativum/ } \\
\text { Garlic }\end{array}$ & Flavonols & $\begin{array}{l}\text { Quercetin, } 1.74 \\
\text { Myricetin, } 1.61 \\
\text { Kaempferol, } 0.26\end{array}$ & $\begin{array}{c}\text { TFC } 100 \mathrm{mg} / \mathrm{g} \text { aged extract; } 47 \mathrm{mg} / \mathrm{g} \\
\text { fresh extract } \\
\text { TFC } 94 \mathrm{mg} / \mathrm{g} \text { aged extract; } 43 \mathrm{mg} / \mathrm{g} \text { fresh } \\
\text { extract } \\
\text { [26] }\end{array}$ \\
\hline & $\begin{array}{l}\text { Asparagus officinalis/ } \\
\text { Asparagus }\end{array}$ & Flavonols & $\begin{array}{c}\text { Quercetin, } 13.98 \\
\text { Ishoramnetin, } 5.70 \\
\text { Kaempferol, } 1.39\end{array}$ & $\underset{[27]}{\mathrm{TFC} 4.7 \mathrm{mg} \mathrm{RE} / \mathrm{g} \mathrm{DW}}$ \\
\hline \multirow[t]{4}{*}{ Apiaceae } & $\begin{array}{l}\text { Daucus carota/ } \\
\text { Carrot }\end{array}$ & $\begin{array}{l}\text { Flavonols } \\
\text { Flavones }\end{array}$ & $\begin{array}{l}\text { Kaempferol, } 0.24 \\
\text { Quercetin, } 0.21 \\
\text { Luteolin, } 0.11\end{array}$ & $\begin{array}{c}\text { TFC 4.7-9.9 mg QE/100 g FW } \\
\text { Isorhamnetin } 41 \mathrm{mg} / \mathrm{Kg} \mathrm{FW} \\
\text { Kaemfperol } 5 \mathrm{mg} / \mathrm{Kg} \mathrm{FW} \\
\text { Quercetin } 9 \mathrm{mg} / \mathrm{Kg} \mathrm{FW} \\
\text { Luteolin } 22 \mathrm{mg} / \mathrm{Kg} \mathrm{FW} \\
{[16,28]}\end{array}$ \\
\hline & $\begin{array}{c}\text { Daucus carota spp. sativus var. } \\
\text { atrorubens / } \\
\text { Purple carrot }\end{array}$ & Anthocyanins & NA & $\begin{array}{c}\text { Total anthocyanins } 1.5-17.7 \mathrm{mg} \\
\text { Cy3GE/100 g FW (mostly cyanidin, } \\
\text { pelargonidin and peonidin galactosides) } \\
{[29]}\end{array}$ \\
\hline & $\begin{array}{l}\text { Petroselinum crispum/ } \\
\text { Parsley }\end{array}$ & $\begin{array}{l}\text { Flavonols } \\
\text { Flavones }\end{array}$ & $\begin{array}{c}\text { Myricetin, } 14.84 \\
\text { Kaempferol, } 1.49 \\
\text { Quercetin, } 0.28 \\
\text { Apigenin, } 215.46 \\
\text { Luteolin, } 1.09\end{array}$ & $\begin{array}{c}\text { TFC } 14 \mathrm{mg} \text { QE/g DW } \\
\text { Kaempferol } 18 \mathrm{mg} / \mathrm{Kg} \mathrm{FW} \\
\text { Quercetin } 5 \mathrm{mg} / \mathrm{Kg} \mathrm{FW} \\
\text { Isorhamnetin } 11 \mathrm{mg} / \mathrm{Kg} \mathrm{FW} \\
\text { Luteolin } 14 \mathrm{mg} / \mathrm{Kg} \mathrm{FW} \\
\text { Apigenin } 4 \mathrm{mg} / \mathrm{Kg} \mathrm{FW} \\
{[16,30]}\end{array}$ \\
\hline & $\begin{array}{l}\text { Coriandrum sativum/ } \\
\text { Coriander }\end{array}$ & Flavonols & Quercetin, 52.90 & $\begin{array}{c}\text { Quercetin } 19 \mathrm{mg} / \mathrm{Kg} \mathrm{FW} \\
\text { Isorhamnetin } 13 \mathrm{mg} / \mathrm{Kg} \mathrm{FW} \\
{[16]}\end{array}$ \\
\hline
\end{tabular}


Table 1. Cont

\begin{tabular}{|c|c|c|c|c|}
\hline Family & $\begin{array}{c}\text { Scientific Name/Common } \\
\text { Name }\end{array}$ & Class of Flavonoids & $\begin{array}{l}\text { Types and Content of Flavonoids } \\
\text { (mg.100 } \mathrm{g}^{-1} \mathrm{FW} \text {, from USDA) }\end{array}$ & $\begin{array}{c}\text { Types and Content of Flavonoids } \\
\text { (Other Sources) }\end{array}$ \\
\hline \multirow[t]{5}{*}{ Asteraceae } & $\begin{array}{l}\text { Lactuca sativa/ } \\
\text { Lettuce }\end{array}$ & $\begin{array}{l}\text { Flavonols } \\
\text { Flavones }\end{array}$ & $\begin{array}{c}\text { Quercetin, } 4.16 \\
\text { Myricetin, } 0.07 \\
\text { Apigenin, } 0.13 \\
\text { Luteolin, } 0.26\end{array}$ & $\begin{array}{c}\text { Quercetin } 32.2 \mathrm{mg} / \mathrm{Kg} \mathrm{FW} \\
\text { Isorhamnetin } 12 \mathrm{mg} / \mathrm{Kg} \mathrm{FW} \\
\text { Luteolin } 2 \mathrm{mg} / \mathrm{Kg} \mathrm{FW} \\
{[16]}\end{array}$ \\
\hline & $\begin{array}{l}\text { Cynara cardunculus / } \\
\text { Cardoon }\end{array}$ & & NA & $\begin{array}{l}\text { TFC } 7 \text { mg CE/g DW (stem) } \\
\text { [31] }\end{array}$ \\
\hline & $\begin{array}{l}\text { Cynara scolymus/ } \\
\text { Artichoke }\end{array}$ & FlavanonesFlavones & $\begin{array}{l}\text { Naringenin, } 12.50 \\
\text { Apigenin, } 7.48 \\
\text { Luteolin, } 2.30 \\
\end{array}$ & $\begin{array}{c}\text { TFC } 13 \text { mg CE/g DW (stem) } \\
{[31]}\end{array}$ \\
\hline & $\begin{array}{l}\text { Chicorium endivia/ } \\
\text { Endive }\end{array}$ & $\begin{array}{l}\text { Flavonols } \\
\text { Flavones }\end{array}$ & Kaempferol, 10.10 & $\begin{array}{c}\text { Quercetin } 30 \mathrm{mg} / \mathrm{Kg} \mathrm{FW} \\
\text { Isorhamnetin } 7 \mathrm{mg} / \mathrm{Kg} \text { FW } \\
\text { Luteolin } 9 \mathrm{mg} / \mathrm{Kg} \mathrm{FW} \\
{[16]}\end{array}$ \\
\hline & $\begin{array}{l}\text { Chicorium intybus/ } \\
\text { Chicory }\end{array}$ & $\begin{array}{l}\text { Flavonols } \\
\text { Flavones }\end{array}$ & $\begin{array}{l}\text { Quercetin, } 6.49 \\
\text { Kaempferol, 2.45 } \\
\text { Luteolin, 2.08 } \\
\text { Apigenin, } 0.77\end{array}$ & $\begin{array}{c}\text { TFC 20-120 mg CE } / \mathrm{Kg} \text { FW } \\
\text { [32] }\end{array}$ \\
\hline \multirow[t]{2}{*}{ Labiateae } & $\begin{array}{l}\text { Ocimum basilicum/ } \\
\text { Basil }\end{array}$ & & NA & $\begin{array}{l}\text { TFC } 12 \mathrm{mg} \text { QE } / \mathrm{g} \text { DW } \\
{[30]}\end{array}$ \\
\hline & $\begin{array}{l}\text { Salvia officinalis/ } \\
\text { Sage }\end{array}$ & Flavones & $\begin{array}{l}\text { Luteolin, } 16.70 \\
\text { Apigenin, } 1.20\end{array}$ & \\
\hline \multirow[t]{2}{*}{ Chenopodiaceae } & $\begin{array}{l}\text { Spinacia oleracea } \\
\text { /Spinach }\end{array}$ & $\begin{array}{l}\text { Flavonols } \\
\text { Flavones }\end{array}$ & $\begin{array}{l}\text { Kaempferol, } 6.38 \\
\text { Quercetin, } 3.97 \\
\text { Myricetin, } 0.35 \\
\text { Luteolin, } 0.74 \\
\end{array}$ & $\begin{array}{c}\text { TFC 1800-3700 mg/Kg FW } \\
\text { Kaempferol } 9 \text { mg/Kg FW } \\
{[16,33]}\end{array}$ \\
\hline & $\begin{array}{l}\text { Beta vulgaris/ } \\
\text { Chard }\end{array}$ & Flavonols & $\begin{array}{l}\text { Kaempferol, } 5.80 \\
\text { Myricetin, } 3.10 \\
\text { Quercetin, } 2.20\end{array}$ & TFC $12 \mathrm{mg}$ QE/g DW \\
\hline Convolvulaceae & $\begin{array}{l}\text { Ipomoea batatas / } \\
\text { Purple sweet potato }\end{array}$ & Anthocyanins & $\begin{array}{l}\text { Cyanidin, } 10.60 \\
\text { Delphinidin, } 0.90 \\
\text { Pelargonidin, } 0.02 \\
\end{array}$ & $\begin{array}{c}\text { TFC } 1.87-3.95 \mathrm{mg} \mathrm{QE} / \mathrm{g} \text { DW } \\
{[34]}\end{array}$ \\
\hline Solanaceae & $\begin{array}{l}\text { Solanum lycopersicum/ } \\
\text { Tomato }\end{array}$ & $\begin{array}{l}\text { Flavanones } \\
\text { Flavonols }\end{array}$ & $\begin{array}{l}\text { Naringenin, } 0.68 \\
\text { Quercetin, } 0.58 \\
\text { Myricetin, } 0.13 \\
\text { Kaempferol, } 0.09\end{array}$ & $\begin{array}{c}\text { TFC 4-26 mg/100 g FW } \\
\text { Kaempferol } 8 \text { mg/Kg FW } \\
{[16,35]}\end{array}$ \\
\hline
\end{tabular}


Table 1. Cont

\begin{tabular}{|c|c|c|c|c|}
\hline Family & $\begin{array}{l}\text { Scientific Name/Common } \\
\text { Name }\end{array}$ & Class of Flavonoids & $\begin{array}{l}\text { Types and Content of Flavonoids } \\
\text { (mg.100 } \mathrm{g}^{-1} \mathrm{FW} \text {, from USDA) }\end{array}$ & $\begin{array}{l}\text { Types and Content of Flavonoids } \\
\text { (Other Sources) }\end{array}$ \\
\hline & $\begin{array}{l}\text { Solanum tuberosum/ } \\
\text { Potato }\end{array}$ & Flavonols & Quercetin, 0.49 & $\begin{array}{c}\text { TFC } 153 \text { mg CE/Kg FW } \\
\text { Kaempferol } 46 \text { mg/Kg FW } \\
\text { Quercetin } 4 \text { mg/Kg FW } \\
\text { Isorhamnetin } 19 \text { mg/Kg FW } \\
{[16,18]}\end{array}$ \\
\hline & $\begin{array}{l}\text { Caspicum annuum/ } \\
\text { Green sweet pepper }\end{array}$ & $\begin{array}{l}\text { Flavonols } \\
\text { Flavones }\end{array}$ & $\begin{array}{c}\text { Quercetin, 2.21 } \\
\text { Kaempferol, 0.06 } \\
\text { Luteolin, } 4.71\end{array}$ & $\begin{array}{c}\text { Luteolin } 2.6 \mathrm{mg} / \mathrm{Kg} \text { FW } \\
{[16]}\end{array}$ \\
\hline & $\begin{array}{l}\text { Caspicum frutescens/ } \\
\text { Green hot chilli pepper }\end{array}$ & $\begin{array}{l}\text { Flavonols } \\
\text { Flavones }\end{array}$ & $\begin{array}{c}\text { Quercetin, } 14.70 \\
\text { Myricetin, } 1.20 \\
\text { Luteolin, } 3.87 \\
\text { Apigenin, } 1.40\end{array}$ & $\begin{array}{c}\text { TFC } 27 \mathrm{mg} \text { CE } / 100 \mathrm{~g} \text { FW } \\
\text { Quercetin } 2 \mathrm{mg} / \mathrm{Kg} \mathrm{FW} \\
\text { Luteolin } 25 \mathrm{mg} / \mathrm{Kg} \mathrm{FW} \\
\text { Apigenin } 5 \mathrm{mg} / \mathrm{Kg} \mathrm{FW} \\
{[16,36]}\end{array}$ \\
\hline & $\begin{array}{l}\text { Solanum melongena/ } \\
\text { Aubergine }\end{array}$ & Anthocyanins & Delphinidin, 85.69 & $\begin{array}{c}\text { Rutin } 9 \mu \mathrm{g} / \mathrm{mg} \text { DW (fruit skin) } \\
\text { Delphinidin-3-rutinoside } 1200 \mu \mathrm{g} / \mathrm{mg} \\
\text { DW (fruit skin) } \\
\text { [37] }\end{array}$ \\
\hline \multirow[t]{2}{*}{ Cucurbitaceae } & $\begin{array}{l}\text { Cucurbita pepo/ } \\
\text { Courgette }\end{array}$ & Flavonols & Quercetin, 0.66 & $\begin{array}{c}\text { Isorhamnetin } 15 \mathrm{mg} / \mathrm{Kg} \mathrm{FW} \\
{[16]}\end{array}$ \\
\hline & $\begin{array}{l}\text { Cucurbita spp./ } \\
\text { Pumpkin }\end{array}$ & $\begin{array}{l}\text { Flavonols } \\
\text { Flavones }\end{array}$ & Luteolin, 1.63 & $\begin{array}{c}\text { TFC 20-40 mg QE/g FW } \\
\text { Isorhamnetin } 35 \mathrm{mg} / \mathrm{Kg} \mathrm{FW} \\
\text { Kempferol } 23 \mathrm{mg} / \mathrm{Kg} \mathrm{DW} \\
\text { Luteolin } 18 \mathrm{mg} / \mathrm{Kg} \mathrm{DW} \\
\text { Apigenin } 9 \mathrm{mg} / \mathrm{Kg} \mathrm{DW} \\
{[16,38]}\end{array}$ \\
\hline
\end{tabular}




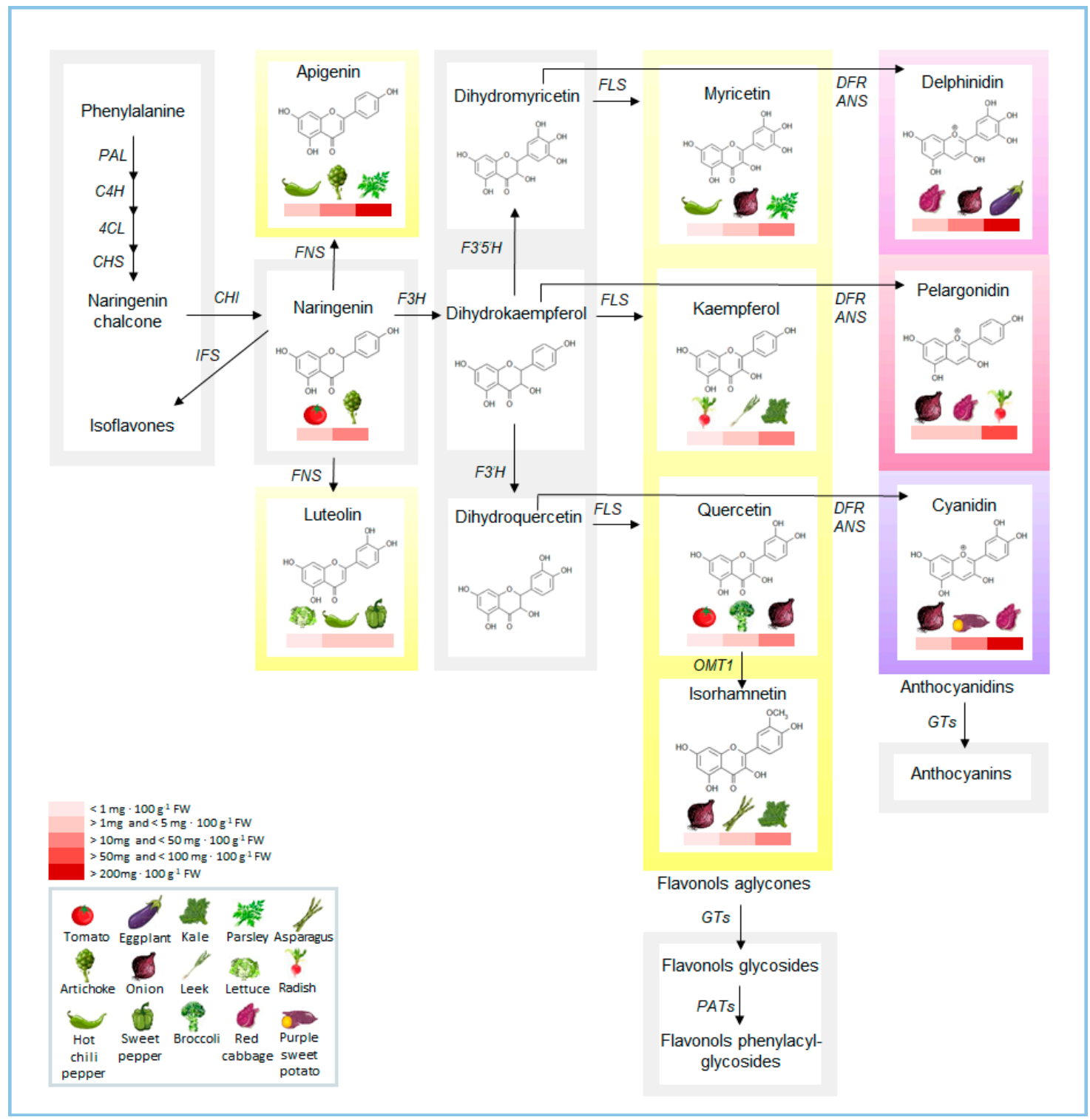

Figure 1. Schematic illustration of the flavonoid biosynthetic pathway, with the main flavonoids in representative horticultural species. Amounts of flavonoids (from USDA database; https://www. ars.usda.gov/nutrientdata [15]) are indicated as a red heatmap ranging from the species with lower to those with higher content. PAL, Phenylalanine ammonia lyase; $\mathrm{C} 4 \mathrm{H}$, cinnamic acid 4-hydroxylase; 4CL, 4-coumarate:coenzyme A ligase; CHS, chalcone synthase; $\mathrm{CHI}$, chalcone isomerase; IFS, isoflavone synthase; FNS, flavone synthase; F3H, flavanone-3-hydroxylase; F3'H, flavanone-3'-hydroxylase; F3'5'H, flavanone-3'5'-hydroxylase; FLS, flavonol synthase; DFR, dihydroflavonol reductase; ANS, anthocyanidin synthase; OMT1, O-methyltransferase 1; GTs, glycosyltransferases; PATs, phenylacyl-transferases.

\section{Flavonoid Pathway in Horticultural Species}

The molecular bases underlying the flavonoid biodiversity consist of a different activation of the genes along the pathway. Most of the key structural enzymes of the central flavonoid metabolism are encoded by single-copy genes, but others are encoded by multiple genes, as in the case of PAL, CHS, F3H, or FLS [39]. The expression of biosynthetic (structural) genes shows a large variation according to the species. The fine regulation of the biosynthetic genes is controlled in an organand tissue-specific manner by MYB, bHLH, and WD40 transcription factors (TFs), which act in an orchestrated ternary complex, indicated as MBW by the initials of each TF. MYBs can be necessary and 
sufficient regulators or can alternatively require the presence of bHLH and/or WD40 partners acting as co-regulators [40]. Another type of regulation is mediated by a post-transcriptional control, since for example the inactivation of PAL can occur by its phosphorylation in association to the enzymatic turnover [41].

In Brassicaceae, such as B. rapa and B. napus, orthologs of the Arabidopsis Transparent Testa (TT)-genes have been identified. For example, BrTT8 regulates proanthocyanidins accumulation in seed coat and the expression of the late flavonoid biosynthetic genes [42]. In B. napus, out of the eighteen genes involved in the flavonoid pathway, nine of these are active in the early stages of seed development, and two as late structural biosynthetic genes. Interestingly, BnTTG2 and BnTT16 regulatory genes are putatively involved in seed color and orchestrate the expression of structural genes [43].

In onion, DNA sequences of several genes of the flavonoid pathway and their assignment to specific chromosomes have been reported [44]. Different loci have been involved in bulb color, as in the case of the $L$ locus, corresponding to an anthocyanidin synthase gene, or the $R$ locus, corresponding to a dihydroflavonol 4-reductase gene [45]. Furthermore, red onion AcMYB1 positively regulates anthocyanin biosynthesis pathway [46]. In a gold-colored onion line, the levels of transcripts of all of flavonoid biosynthetic genes are similar to those observed in red onions [47]. However, in this gold line, a premature stop codon in the coding region of the $\mathrm{CHI}$ gene is responsible of the inactivation of the $\mathrm{CHI}$ gene, thus inducing a block in the flavonoid biosynthesis pathway and the accumulation of chalcone derivatives, conferring the bright yellow color [47]. However, this is not an isolated case of $\mathrm{CHI}$ block, since a similar bottleneck in the flavonoid pathway has been also reported from tomato [48]. In this species, the introduction of heterologous $\mathrm{CHI}$ by transgenic approach resulted in increased levels of quercetin glycosides located downstream the CHI catalyzed step [49].

While in most horticultural varieties the activation of flavonoid and anthocyanin biosynthetic genes have been mainly observed in response to the light [50], in purple-colored carrots the reasons of this activation are still unclear. The purple or purple-orange carrots have their origins in the oriental countries and were commonly consumed before the domestication and introduction of the orange carrots occurred in the 17th century in Europe, probably in Netherlands [51]. However, some varieties and local landraces still exist [52,53], and in some cases the flavonoid and anthocyanin pathway has been investigated. Yildiz et al. (2013) [54] reported that five anthocyanins biosynthesis genes and three anthocyanin transcription factors map in a population segregating for the $P 1$ locus that influence the purple root color. Yet, either the structural biosynthetic genes [55] and TF [56] were found highly expressed in the purple carrots compared to the yellow or orange ones. One of these, the DcMYB6 gene, shares high identity with anthocyanin-regulating MYBs from other species [56], but it remains unclear if DcMYB6 requires bHLH cofactors or its activation is sufficient to trigger the expression of anthocyanin genes in below ground tissues.

In red-purple spinach, the expression patterns of the SoPAL, SoUFGT3, SoUFGT4, and regulatory MYB, bHLH, and WD40 genes have been reported, thus confirming their important role in anthocyanin biosynthesis in this species [57]. In globe artichoke, the role of the regulatory gene CcMYB12 was investigated in heterologous models, where it resulted in a positive regulation on the flavonol biosynthesis [58].

The accumulation of anthocyanins is one of the most studied pathways in potato, since pigmented potato cultivars are considered a good source of these phytochemicals at levels similar to blueberries, blackberries, cranberries, and grape [59]. Similarly to other species, potato shows the presence of several genetic loci specifically controlling anthocyanin biosynthesis [59]. Key regulators of the phenylpropanoid and anthocyanin pathway are StAN1, StAN2, StMYBA1, and StMYB113, but a crucial role is also played by bHLH co-factors, since StAN1 and StAN2 interact with StbHLH1 and StJAF13 in different organs, i.e., leaf and tuber [59,60]. Among other transcription factors encoding genes affecting the anthocyanin accumulation in potato, StAN11, a WD40-repeat gene, has been proposed as a regulator of the pathway by controlling the expression of DFR [61]. Furthermore, the ScAN2 MYB transcription factor has been found induced by low temperatures in the potato cold-tolerant species 
Solanum commersonii. Interestingly, ScAN2 is a paralog of ScAN1, even though ScAN2 is less able to induce anthocyanin than ScAN1, having in turn the ability to induce hydroxycinnamic acids [62].

Flavonoid biosynthesis and its regulation have been particularly studied in tomato over the years. In the flesh of this fruit, all flavonoid genes are scarcely expressed and flavonoids are accumulated in very low amounts. Conversely, the peel accumulates naringenin chalcone and rutin as major flavonoids detected during the fruit ripening process [1]. In this tissue, CHS, responsible of naringenin chalcone production, is highly expressed but not $\mathrm{CHI}$, which is required to convert naringenin chalcone into naringenin. The low expression of $\mathrm{CHI}$ suggests that it is a rate-limiting step for flavonoid production in tomato [1]. The orthologue of the Arabidopsis MYB12 gene [40,63] has been identified and characterized in tomato (SIMYB12) [64]. SIMYB12 expression increases markedly during the green and green-yellow fruit developmental stages and it is implicated in caffeoyl quinic acids (CQAs) and flavonol biosynthesis [64]. Recent insights using a metabolomic and transcriptomic integrated approaches revealed implications of SIMYB12 in a more extended metabolic network (for example, some influences on polyamine biosynthesis pathway) [65]. In other studies, members of MBW complex have been identified as regulators of anthocyanin biosynthesis, such as SIANT1 and SIAN2 (MYB TFs) [66,67] both mapping to tomato chromosome 10. Recently, the WD40 TF named SIAN11 has been characterized and proposed to promote plant anthocyanin and seed proanthocyanidin (PA) contents [68].

\section{Environmental Factors Affecting Flavonoid Composition in Horticultural Crops}

Beside genomic factors, environmental conditions and agronomic practices also affect flavonoid levels in horticultural species. Flavonoid content shows deep variations during different stages of fruit ripening, but light and temperature can also greatly influence their levels. UV-B exposition can trigger the anthocyanin biosynthesis, whereas variations in the photoperiod, light intensity, and wavelength can stimulate differently the flavonoid pathway [69]. In fact, most of the structural and regulatory genes of this pathway are light-responsive [70]. Positive effects following light exposure have been found in tomato [71]. In broccoli and kale, flavonoids concentration increases with high photosynthetic active radiation (PAR) $[72,73]$ and qualitative differences in flavonol content have been reported after UV-B radiation [74]. An improvement in the flavonoid content after UV-B irradiation has been also described in sweet basil [75]. Temperature can influence the rate of biochemical reactions catalyzed by different enzymes and affect phytochemical accumulation in plants [76]. Furthermore, during fruit development, variation in temperatures can affect photosynthesis, respiration, and secondary metabolism. Qualitative changes in the flavonol profile have been found after low temperature treatments between 0.3 and $9.6^{\circ} \mathrm{C}$ in broccoli and kale [77].

Irrigation and nutrition are cultural practices that can further affect the flavonoid content in vegetables. Water stress has been reported inducing the transcription of genes encoding $\mathrm{PAL}, \mathrm{C} 4 \mathrm{H}$, 4CL, CHI, and F3H [78]. Deficit of irrigation in three leafy lettuce varieties induced an increase of flavonols i.e., kaempferol, myricetin, and quercetin [79]. Water stressed lettuce plants have also displayed increased levels of total phenolic content and antioxidant capacity [80].

Several studies related the flavonoid content in horticultural crops to the presence of nitrogen or organic inputs in the soil [81]. Interestingly, organic fertilizers functioned as a sink from which the flux of primary metabolites feeds secondary metabolism. A decrease in flavonoids has been mainly correlated to nitrogen supply [81]. A possible explanation resides in the carbon/nutrient balance (CNB) hypothesis, according to which, low nitrogen availability induces an increase in carbon availability and thus carbon-based secondary metabolites [70]. In red basil [82] and broccoli [83], a decrease in flavonoid content has been observed following nitrogen fertilization. In another study, tomato fruits from plants grown with low nitrogen supply showed a higher phenolic content [84]. In a field experiment on broccoli cultivars, high flavonoids levels have been detected in response to soil organic fertilization. However, another study, in which organic treatment and winter cover crop was experimented, did not result in any significant increase in flavonoid content [85]. These data suggest that agronomic practices, i.e., organic or conventional management, growing location (growth 
in plots or fields, in greenhouse or open fields) and environmental conditions (light, temperature) have to be carefully applied and evaluated for each plant species in the perspective of increasing flavonoid content [81].

\section{Effects of Processing on Flavonoids Content}

Stems, leaves, roots, inflorescences, or fruits of horticultural crops are generally consumed as fresh foods or often, variously processed in industrial or homemade preparations. Processing of fresh food products can generally modify organoleptic and nutritional properties, since many volatile compounds or phytochemicals like macro or micronutrients (carbohydrates, amino acids, minerals, vitamins, phenols, etc.) can be transformed or destroyed. Crushing, pressing, and temperature-dependent treatments can deeply impact on the flavonoid content [86], with consequences on their bioactivity. These processes generally disrupt in mechanic way plant tissues and subsequently cell wall, thus favoring the solubilization of phytochemicals. Mechanical disruption can break the structure itself of phytonutrients and in addition, it can release enzymes that can promote the degradation of biocompounds. For example, flavonoids can be oxygenated and degraded by several enzymes (polyphenol oxidases, peroxydases, glycosidases, esterases) that are released when plant cells are broken down. Glycosidase and esterase enzymes catalyze flavonoid degradation during hydrolysis reactions. Oxidation reactions caused by polyphenol oxidases and peroxidases tend to blacker pigments, thereby having negative effects on quality of fresh vegetables and fruits [87].

In asparagus spears, domestic preparations like peeling significantly reduced flavonoid content, after storage at $2{ }^{\circ} \mathrm{C}$ [88]. Similarly, cutting has been showed to reduce significantly the content of rutin in this species [89], but this practice seems to not affect quercetin 3,4'-glucoside and quercetin 4 '-glucoside content, and the overall antioxidant capacity of onion [89].

High temperatures were also reported as one of the main treatment responsible of the reduction of flavonoids and anthocyanins in processed fruits and vegetables (as in the case of flavonols of asparagus and onions; [89]), and phenolic compounds and flavonoids (particularly kaempferol and quercetin, in carrots, courgettes, and broccoli; [90]). In tomato, a $80 \%, 65 \%$, and $30 \%$ reduction in quercetin levels were reported after boiling, microwave cooking, and frying, respectively [91].

This large literature body clearly points that processing strongly modifies the phytochemical composition of fruits and vegetables, with a general decrease in their nutritional quality. However, beside the fact that cooking makes foods more digestible, high temperature treatments are usually employed to destroy microorganisms and sanitize food products. Emerging alternatives to these invasive treatments i.e., mild non-thermal treatments, as in the case of high-pressure and plasma treatments have been proposed [92], providing the possibility to use these technologies to preserve food from pathogen contamination and unwanted enzymatic activities and at the same time to potentially extend the shelf life and nutritional value of food crops.

\section{Flavonoids Biofortification}

Biofortification consists of a number of strategies aimed at increasing the content of compounds considered beneficial for human health. Such an increase can be reached by application of specific fertilizers for plant nutrition, but also using breeding or metabolic engineering approaches by which it is possible to increase the synthesis of phytochemicals or even induce the production of new compounds without any intervention during the pre/post-harvest steps [93]. Breeding or metabolic engineering programs in the context of flavonoid biofortification has been usually used to enrich crop species that naturally are unable to accumulate optimal amounts of specific bio-compounds. As for other phytochemicals, the enrichment of flavonoids by breeding depends on the availability of genetic resources and variability. Genetic screening of wild cultivars and landraces is helpful to identify specific traits which can be later introgressed in domesticated varieties [94]. Potato breeding strategies for anthocyanin enhancement have been proposed using some South American cultivars, as interesting sources of flavonoids [62]. Another good example of anthocyanin improvement refers to tomato. 
In this species, the dominant Aft (Anthocyanin fruit) gene has been introgressed in a domesticated cultivar by crossing with $S$. chilense and the recessive atv (atroviolacea) gene by interspecific cross with $S$. cheesmaniae. The resulting tomato plants were double mutants, carrying both Aft and atv alleles (Aft/Aft atv/atv), and accumulated anthocyanins in the fruit skin until ripening, strongly stimulated by light and cold [95]. Another interesting example of breeding for anthocyanin enrichment has been realized using a white Chinese cabbage as female parent and zicatai (Brassica rapa L. ssp. chinensis var. purpurea) as male parent, resulting in a purple heading Chinese cabbage line rich in anthocyanins [96,97].

Wild garlic germplasm has been also used as a viable option for breeding strategies to increase the flavonoid content in this species. Allium ursinum (wild garlic) and A. victorialis contain genetic traits for novel flavonoids, which could be introgressed in A. sativum. So far, garlic breeding has been limited to clonal selection of wild varieties or natural mutants, but a recently developed routine seed production will be useful for introgression of genes from wild relatives [98].

Metabolic engineering can be also a useful tool for flavonoids enrichment. So far, two strategies that make use of structural or regulatory genes have been developed, sometimes used in combination (Figure 2). The first one consists of the introduction of novel branches, mediated by transgenic insertion of new genes not present in the genome, or alternatively the selective inactivation of genes involved in metabolic fluxes [1,63]. The second strategy consists of over-expression of genes encoding transcription factors that modulate different steps of the pathway [1]. For example, a single or simultaneous over-expression of $C H S, C H I$, and DFR structural genes resulted in a significant increase in flavonoid and anthocyanins in potato, accompanied by a decrease of starch and glucose levels [99]. A potato UDP-glucose:flavonoid-3-O-glucosyltransferase (3GT) has been over-expressed resulting in increased anthocyanins content in tuber skin [100]. Another study reported high amounts of anthocyanins, kaempferol, chlorogenic acid, sinapic acid, and proanthocyanins in transgenic potato plants over-expressing DFR and UGT [101].

In tomato, one of the first attempts to improve flavonoid production made use of structural genes limiting the flavonoid biosynthesis. The over-expression of Petunia CHI gene, as an example, resulted in increase of the flavonol content in the peel $[49,102]$. Another strategy to improve flavonoids content consisted of the use of regulatory genes. For example, ectopic over-expression of the maize leaf color $(L C)$ and colorless $\mathrm{C} 1$ regulatory genes led to the accumulation of anthocyanins in leaves and other flavonoids like kaempferol glycosides in the fruit of tomato [103]. An increase in flavonoid levels has been also reached by suppressing the DET1 (De-etiolated) regulatory gene combining a RNAi approach with the use of fruit-specific promoters [104]. Zhang et al. (2016) [105] showed that the introduction of SmMYB1 into a non-anthocyanin-producing eggplant cultivar, induced high accumulation of anthocyanin in plant tissues and highly methylated anthocyanins mainly in fruit flesh, with a higher tolerance to freezing stress observed in transgenic lines. High accumulation of anthocyanins in both flesh and peel of tomato fruit has been reached by using the snapdragon transcription factors Delila and Rosea [106]. Furthermore, the over-expression of the AtMYB12 in tomato was successful to reach high levels of CQAs and flavonols in the whole fruit [64]. These examples clearly indicate the great potential of the transcription factors as valuable biotechnological tools for an effective enhancement of nutritionally important phytochemicals.

A combination of different TFs was also employed to obtain high accumulation of different classes of flavonoids, as it has been reported for the Indigo tomato line, obtained by crossing the lines over-expressing AtMYB12 and Del/Ros [63]. This work case also demonstrated the "pushing" function that the AtMYB12 transcription factor exerts on the whole flavonoid metabolic flux. In fact, the combined over-expression of the AtMYB12 gene and the IFS (isoflavone synthase) gene resulted in the accumulation of high levels of flavonols and isoflavones in the whole fruits. The crossing of transgenic lines has been also described in another study, in which tomato lines over-expressing the onion $\mathrm{CHI}$ gene and the Arabidopsis PAP1 (Production of Anthocyanin Pigment 1) gene, upregulating the early biosynthetic genes, were crossed to obtain $\mathrm{CHI} \times \mathrm{PAP} 1$ lines. The resulting tomato line accumulated 
higher levels of rutin and anthocyanins in the fruit skin compared to wild type tomatoes [107]. If in most of the cases, flavonoid biofortification has been realized by classic transgenic approaches, emerging genome editing technologies are revealing their great potential in the improvement of plant food quality. CRISPR/Cas9-mediated genome editing is one of the most promising technologies to reach this scope. Despite many efforts, studies are still needed, and some data indicate that biofortification is possible through this approach $[108,109]$, even though a molecular editing plan, plant regeneration, and accurate screening methods have to be carefully addressed for each plant species [109].

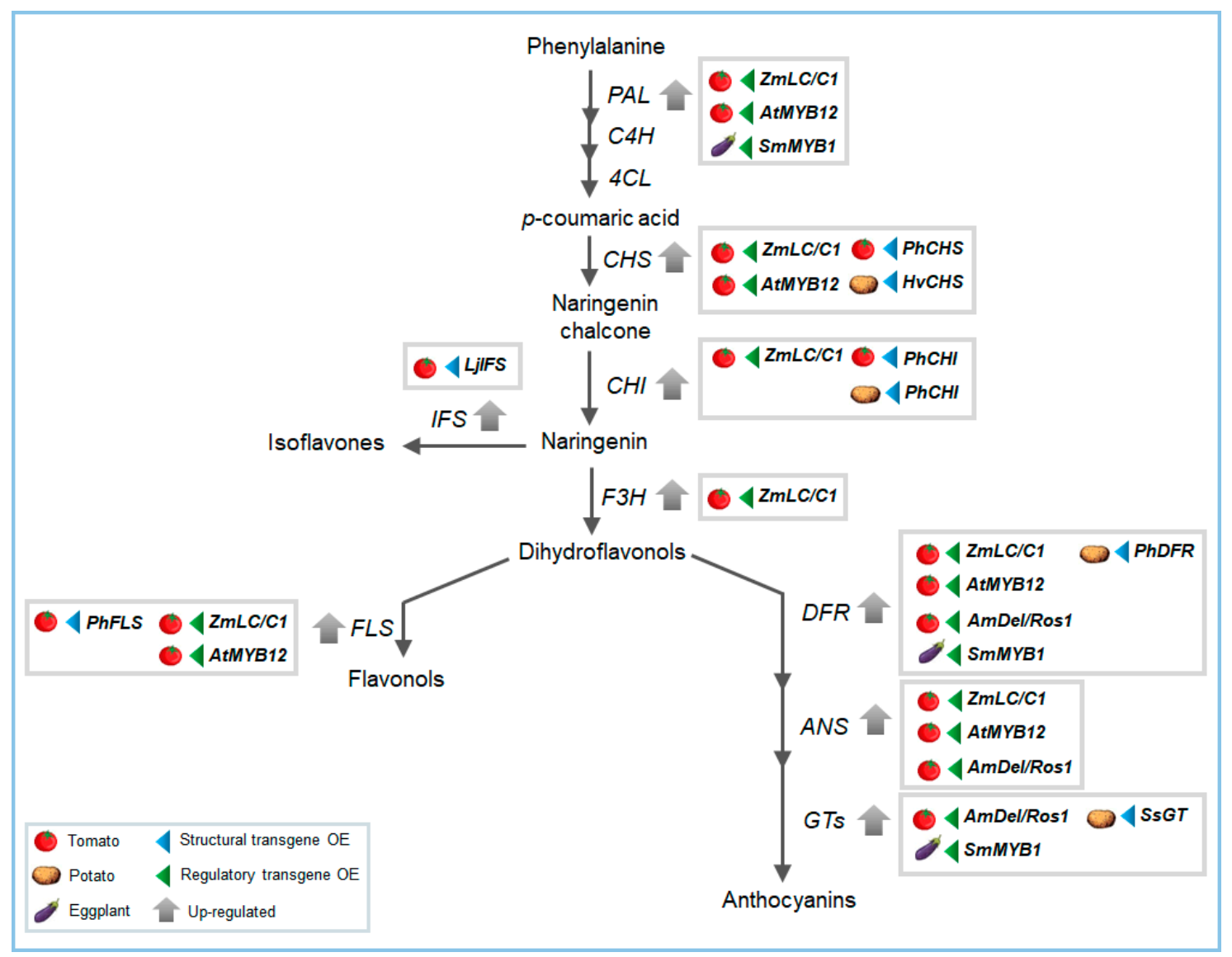

Figure 2. Flavonoid biofortification by metabolic engineering strategies through the use of structural (blue arrow on the right of the boxes) or regulatory genes' (green arrow on the left of the boxes) over-expression (OE). The scheme reports the main genes targets studied for flavonoids improvement in horticultural species.

\section{Flavonoids in Plant Food Quality and Nutritional Aspects}

Flavonoids contribute to the quality of horticultural crops, contributing either to their organoleptic or nutritional quality. Color is one of the sensory parameters highly determining the degree of acceptability of plant food products. Flavonoids, and especially anthocyanins, are among the most popular natural pigments conferring the color to fruits and vegetables, together with chlorophylls (green), carotenoids (yellow, orange and red), and betalains (red and purple) [110]. Flavonoids like flavanols (i.e., catechins and epicatechins), flavonols (i.e., rutin, quercetin), flavanones (i.e., hesperetin, naringenin), chalcones, and flavones (i.e., luteolin) usually contribute to the range of ivory/bright yellow colors in plant foods.

Flavonoids like isoflavones or proanthocyanidins play also an important role in the sensation of bitterness and astringency. The perception of bitterness has been linked to structural signatures, such as the presence of aromatic rings or carboxylic acid groups [111]. Sensation of astringency has been reported to be due to the precipitation of salivary proteins following their interaction with polymeric 
proanthocyanidins [112], a perception that makes them unpalatable and can be considered a defense mechanism of plants towards herbivorous animals [113].

Considering food quality, anthocyanins, for example, act as antioxidant compounds contrasting ROS activities, thus extending the shelf-life of fruits [114,115]. Furthermore, flavonoids display antibacterial properties against a wide range of pathogenic microorganisms. Several mechanisms have been proposed, ranging from the inhibition of nucleic acid synthesis and biofilm formation to the alteration of membrane permeability [116].

Flavonoids contribute significantly to the nutritional properties of plant food and their accessibility to human gut is an important feature. In fact, the bio-efficacy of flavonoids is largely dependent on their bioavailability. For example, the physical and chemical composition of food matrices may delay or enhance flavonoids digestibility and absorption. Proteins, dietary fibers (hemicellulose, pectins), lipids, and other phytochemicals can also influence their bioavailability. For example, the carbohydrate composition of the food matrix has been reported to modulate flavonol absorption in the small intestine [117].

In the human body, flavonoids undergo several modifications catalyzed by enzymatic activities during absorption and digestion and, afterwards, they are substrates of biotransformation occurring by gut microbiota. Reactions of oxidation or hydrolysis to release aglycones, or the conjugation with O-glucuronides or methyl esters in the enterohepatic circle, have the function to increase the hydrophilicity and render flavonoids more transportable in the bloodstream, charged by plasmatic proteins, and render them more absorbable in the small intestine. Uptake of flavonoids at the intestinal barrier is generally mediated by passive diffusion or transporters located into the lipid bilayer of intestinal epithelial cells membrane [118,119]. Isoflavone aglycones are transported into enterocytes more efficiently than their glycosylated forms, due to their lipophilicity [119] and easier absorption [120]. Transport of quercetin $4^{\prime}-\beta$-glucoside across the apical membrane of enterocytes has been reported mediated by SGLT1 (sodium-dependent d-glucose cotransporter-1) [121]. (-)-epichatechin-3-gallate, a flavan-3-ol, is absorbed by the monocarboxylic acid transporter (MCT), as well as ferulic acid, $p$-coumaric acid, or caffeic acid [122]. Rutin and naringin are mainly absorbed from the distal part of the intestine after hydrolysis by colonic microflora intestinal enzymes and $\beta$-glucosidases [122].

In the large intestine, flavonoids can be further converted by gut microbiota in simple aromatic compounds. Even though flavonoids are biotransformed at the intestinal level, byproducts obtained from these reactions can still be active and exert antioxidant or anti-inflammatory properties [123]. Flavonoids are also known to modulate microbiota, inducing a remodelling of bacterial communities and genera in the microbiota environment, thus acting as prebiotics [124].

Although there are many studies reporting the beneficial activities of flavonoids and anthocyanins, the majority of them consider the administration of synthetic compounds (pure flavonoid standards), which does not fully reflect the effects of the whole food matrices of fruits and vegetables. From this point of view, it is important to elucidate the role of flavonoids on human health within their natural matrices and normal diet conditions. Focusing on this type of study, in vitro and in vivo assays have shown the following nutraceutical benefits:

(i) Anti-cancer activity. Among the major mechanisms studied to test the efficacy of flavonoids in the protection against different types of cancer, there are the induction of apoptosis in vitro or reduction of tumor incidence in vivo, and the inactivation of p53 protein, which plays an important role in cell cycle regulation, tumor suppression, and protection against oxidative damage. In a cell proliferation assay on human breast cancer cell lines, crude onion extracts showed a higher cytotoxic activity than purified quercetin and kaempferol [125]. Purple potatoes exerted positive effects against colon cancer stem cells in mice, with a suppression of tumor incidence [126]. In another study, a purple-fleshed sweet potato diet induced preventive benefits without toxicity in a colorectal cancer mouse model [127]. A significant increase of the average 
life span has been shown in Trp53-/- knockout mice fed with purple tomato-enriched diet, suggesting a protective effect against cancer progression [106].

(ii) Hypoglycemic effects and antioxidant activities. Some studies have investigated the positive hypoglycemic effects of onion skin extract on diabetes mellitus and spikes in postprandial blood glucose in animal models ([128] and references therein). Flavonoids from artichoke extracts lowered blood sugar in normal and obese rats [129], even if the mechanism of action has not been elucidated. The beneficial effects in lowering glucose can be linked to the ability of flavonoids to reduce vascular nitric oxide (NO) production, lipid peroxidation, and the pre-oxidant enzymes (superoxide dismutase, catalase, and glutathione peroxidase), all implicated in the onset of tissue oxidative stress, involved in several human diseases. This fact is particularly interesting considering that the state of oxidation/antioxidation imbalance generates complications in a number of human pathologies i.e., diabetes and obesity [130]. A study on endothelial cells showed that artichoke flavonoids upregulate the nitric-oxide synthase (eNOS) expression, an effect particularly important in regulating vascular function. In fact, eNOS balances vasodilatation and vasoconstriction mediated by nitric oxide (NO) and superoxide, respectively [130].

(iii) Anti-bacterial activity. In vitro studies suggest an antimicrobial activity of onion extract on pathogenic isolates of Escherichia coli, Staphylococcus aureus, Streptococcus, and Streptococcus pneumonia [131]. Garlic extracts are also well known for showing antimicrobial activities [132]. The antibacterial activity of flavonoids might be due to molecular interactions inducing inactivation of microbial proteins, like adhesins or membrane transport proteins, altering membrane permeability, and interfering with cell growth [124,133]. Different behavior between Gram-positive and Gram-negative bacteria has been reported after flavonoid exposure. This could be likely explained by differences in cell wall composition and can explain at least in part the prebiotic effects on the bacterial communities in human gut microbiota [123].

(iv) Anti-inflammatory and immune-modulatory activities. In vitro data indicate that flavonoids can modulate the inflammatory response, interfering in the major intracellular signaling pathways (i.e., NFkB, MAPKs) and decreasing the production of pro-inflammatory interleukins [134]. In a model of murine colonic epithelial cells, the administration of high-flavonols and high-anthocyanins tomato extracts reduced the production of IL-6 and TNF $\alpha$ interleukins, and the migration of primary leukocytes and dendritic cells, which are implicated in the immune responses. Furthermore, high-flavonols and high-anthocyanin tomato extracts inhibited the SAPK/JNK and p38MAPK inflammatory signaling pathways [135]. Administration of a tomato diet enriched in flavonoids and anthocyanins contributed to the reduction of inflammatory bowel diseases symptoms in a mouse model of ulcerative colitis [136]. Finally, red onion extracts have also shown immune-modulatory effects in an experimentally induced prostatic hyperplasia of rats [137].

\section{Concluding Remarks}

A growing body of evidence highlights the great versatility and plasticity of the flavonoid secondary metabolism among land plant species, focusing many efforts on the biodiversity and complexity of their chemical structures. Nevertheless, other studies are necessary to better elucidate flavonoid metabolism (for example, phytochemical composition, biosynthesis regulation, and genetic bases) in many less-studied horticultural crops. The chemical variety represents a mine of information either on the evolution/adaptation at specific (and often restrictive) environmental conditions, or the nutritional value of edible species. The biofortification strategies aimed at the improvement of these phytochemicals and thus the nutritional value of plant food products will offer the opportunity to develop new enriched plant foods, useful either in healthy or pathological conditions in the prevention or as pharmacological treatment adjuvant of important human pathologies. Further information from studies testing the effects of whole food matrices using more accurate animal models of important human pathologies will, therefore, be crucial to define the suitable amounts of specific phytochemicals in customized nutritional programs. 
Author Contributions: A.S. (Aurelia Scarano) and A.S. (Angelo Santino) wrote the paper. All the Authors critically revised the manuscript.

Funding: This research was in part founded by the Apulia Region; projects NATURE (XUANRO4) and SICURA (KC3U5Y1).

Conflicts of Interest: The authors declare no conflict of interest.

\section{References}

1. Bovy, A.; Schijlen, E.; Hall, R.D. Metabolic engineering of flavonoids in tomato (Solanum lycopersicum): The potential for metabolomics. Metabolomics 2007, 3, 399-412. [CrossRef] [PubMed]

2. Falcone Ferreyra, M.L.; Rius, S.P.; Casati, P. Flavonoids: Biosynthesis, biological functions, and biotechnological applications. Front. Plant Sci. 2012, 3, 222. [CrossRef] [PubMed]

3. Mouradov, A.; Spangenberg, G. Flavonoids: A metabolic network mediating plants adaptation to their real'estate. Front. Plant Sci. 2014, 5, 620. [CrossRef] [PubMed]

4. Tohge, T.; Fernie, A.R. Leveraging natural variance towards enhanced understanding of phytochemical sunscreens. Trends Plant Sci. 2017, 2, 308-315. [CrossRef] [PubMed]

5. Yonekura-Sakakibara, K.; Hanada, K. An evolutionary view of functional diversity in family 1 glycosyltransferases. Plant J. 2011, 66, 182-193. [CrossRef] [PubMed]

6. Ishihara, H.; Tohge, T.; Viehöver, P.; Fernie, A.R.; Weisshaar, B.; Stracke, R. Natural variation in flavonol accumulation in Arabidopsis is determined by the flavonol glucosyltransferase BGLU6. J. Exp. Bot. 2015, 67, 1505-1517. [CrossRef] [PubMed]

7. Hu, C.; Gong, Y.; Jin, S.; Zhu, Q. Molecular analysis of a UDP-glucose: Flavonoid 3-O-glucosyltransferase (UFGT) gene from purple potato (Solanum tuberosum). Mol. Biol. Rep. 2011, 38, 561-567. [CrossRef] [PubMed]

8. Hu, M.; Lu, Z.; Guo, J.; Luo, Y.; Li, H.; Li, L.; Gao, F. Cloning and characterization of the cDNA and promoter of UDP-glucose: Flavonoid 3-O-glucosyltransferase gene from a purple-fleshed sweet potato. S. Afr. J. Bot. 2016, 106, 211-220. [CrossRef]

9. Moreno, D.A.; Pérez-Balibrea, S.; Ferreres, F.; Gil-Izquierdo, A.; Garcìa-Viguera, C. Acylated anthocyanins in broccoli sprouts. Food Chem. 2010, 123, 358-363. [CrossRef]

10. Tamura, S.; Tsuji, K.; Yongzhen, P.; Ohnishi-Kameyama, M.; Murakami, N. Six new acylated anthocyanins from red radish (Raphanus sativus). Chem. Pharm. Bull. 2010, 58, 1259-1262. [CrossRef] [PubMed]

11. Cartea, M.E.; Francisco, M.; Soengas, P.; Velasco, P. Phenolic compounds in Brassica vegetables. Molecules 2011, 16, 251-280. [CrossRef] [PubMed]

12. Goda, Y.; Shimizu, T.; Kato, Y.; Nakamura, M.; Maitani, T.; Terahara, N.; Yamaguchi, M. Two acylated anthocyanins from purple sweet potato. Phytochemistry 1997, 44, 183-186. [CrossRef]

13. Tohge, T.; Zhang, Y.; Peterek, S.; Matros, A.; Rallapalli, G.; Tandrón, Y.A.; Butelli, E.; Kallam, K.; Hertkorn, N.; Mock, H.-P.; et al. Ectopic expression of snapdragon transcription factors facilitates the identification of genes encoding enzymes of anthocyanin decoration in tomato. Plant J. 2015, 83, 686-704. [CrossRef] [PubMed]

14. Tohge, T.; Wendenburg, R.; Ishihara, H.; Nokabayashi, R.; Watanabe, M.; Sulpice, R.; Hoefgen, R.; Takayama, H.; Saito, K.; Stitt, M.; et al. Characterization of a recently evolved flavonol-phenylacyltransferase gene provides signatures of natural light selection in Brassicaceae. Nat. Commun. 2016, 7, 12399. [CrossRef] [PubMed]

15. USDA Database for the Flavonoid Content of Selected Foods. Release 3.2. September 2015. Available online: https:/ / www.ars.usda.gov/nutrientdata (accessed on 1 October 2018).

16. Cao, J.; Chen, W.; Zhang, Y.; Zhang, Y.; Zhao, X. Content of selected flavonoids in 100 edible vegetables and fruits. Food Sci. Technol. Res. 2010, 16, 395-402. [CrossRef]

17. Rokayya, S.; Li, C.-J.; Zhao, Y.; Li, Y.; Sun, C.-H. Cabbage (Brassica oleracea L. var. capitata) phytochemicals with antioxidant and anti-inflammatory potential. Asian Pac. J. Cancer Prev. 2013, 14, 6657-6662. [CrossRef]

18. Karadeniz, F.; Burdurlu, H.S.; Koca, N.; Soyer, Y. Antioxidant activity of selected fruits and vegetables grown in Turkey. Turk. J. Agric. For. 2005, 29, 297-303.

19. Scalzo, R.L.; Genna, A.; Branca, F.; Chedin, M.; Chassaigne, H. Anthocyanin composition of cauliflower (Brassica oleracea L. var. botrytis) and cabbage (B. oleracea L. var. capitata) and its stability in relation to thermal treatments. Food Chem. 2008, 107, 136-144. [CrossRef]

20. Ahmed, F.A.; Ali, R.F.M. Bioactive compounds and antioxidant activity of fresh and processed white cauliflower. BioMed Res. Int. 2013, 2013, 367819. [CrossRef] [PubMed] 
21. Fernandes, F.; Valentão, P.; Sousa, C.; Pereira, J.A.; Seabra, R.M.; Andrade, P.B. Chemical and antioxidative assessment of dietary turnip (Brassica rapa var. rapa L.). Food Chem. 2007, 105, 1003-1010. [CrossRef]

22. Park, C.H.; Baskar, T.B.; Park, S.-Y.; Kim, S.-J.; Arasu, M.V.; Al-Dhabi, N.A.; Kim, J.K.; Park, S.U. Metabolic profiling and antioxidant assay of metabolites from three radish cultivars (Raphanus sativus). Molecules 2016, 21, 157. [CrossRef] [PubMed]

23. Koh, E.; Wimalasiri, K.M.S.; Chassy, A.W.; Mitchell, A.E. Content of ascorbic acid, quercetin, kaempferol and total phenolics in commercial broccoli. J. Food Comp. Anal. 2009, 22, 637-643. [CrossRef]

24. Slimestad, R.; Fossen, T.; Vågen, I.M. Onions: A source of unique dietary flavonoids. J. Agric. Food Chem. 2007, 55, 10067-10080. [CrossRef] [PubMed]

25. Radovanovic, B.; Mladenović, J.; Radovanovic, A.; Pavlović, R.; Nikolić, V. Phenolic composition, antioxidant, antimicrobial and cytotoxic activities of Allium porrum L. (Serbia) extracts. J. Food Nutr. Res. 2015, 3, 564-569.

26. Elosta, A.; Slevin, M.; Rahman, K.; Ahmed, N. Aged garlic has more potent antiglycation and antioxidant properties compared to fresh garlic extract in vitro. Sci. Rep. 2016, 7, 39613. [CrossRef] [PubMed]

27. Sun, T.; Powers, J.R.; Tang, J. Evaluation of the antioxidant activity of asparagus, broccoli and their juices. Food Chem. 2007, 105, 101-106. [CrossRef]

28. Leja, M.; Kamińska, I.; Kramer, M.; Maksylewicz-Kaul, A.; Kammerer, D.; Carle, R.; Baranski, R. The content of phenolic compounds and radical scavenging activity varies with carrot origin and root color. Plant Foods Hum. Nutr. 2013, 68, 163-170. [CrossRef] [PubMed]

29. Cuevas Montilla, E.; Rodriguez Arzaba, M.; Hillebrand, S.; Winterhalter, P. Anthocyanin composition of black carrot (Daucus carota ssp. sativus var. atrorubens Alef.) cultivars Antonina, Beta Sweet, Deep Purple, and Purple Haze. J. Agric. Food Chem. 2011, 59, 3385-3390.

30. Chandra, S.; Khan, S.; Avula, B.; Lata, H.; Yang, M.H.; ElSohly, M.A.; Khan, I.A. Assessment of total phenolic and flavonoid content, antioxidant properties, and yeld of aeroponically and conventionally grown leafy vegetables and fruit crops: A comparative study. Evid. Based Complement. Altern. Med. 2014, 2014, 253875. [CrossRef] [PubMed]

31. Soumaya, K.; Chaouachi, F.; Ksouri, R.; El Gazzah, M. Polyphenolic composition in different organs of Tunisia populations of Cynara cardunculus L. and their antioxidant activity. J. Food Nutr. Res. 2013, 1, 1-16.

32. Montefusco, A.; Semitaio, G.; Marrese, P.P.; Iurlaro, A.; De Caroli, M.; Piro, G.; Dalessandro, G.; Lenucci, M.S. Antioxidants in varieties of chicory (Cichorium intybus L.) and wild Poppy (Papaverus rhoeas L.) of Southern Italy. J. Chem. 2015, 2015, 923142. [CrossRef]

33. Cho, M.J.; Howard, L.R.; Prior, R.L.; Morelock, T. Flavonoid content and antioxidant capacity of spinach genotypes determined by high-performance liquid chromatography/mass spectrometry. J. Sci. Food Agric. 2008, 88, 1099-1106. [CrossRef]

34. Ghasemzadeh, A.; Omidvar, V.; Jaafar, H.Z.E. Polyphenolic content and their antioxidant activity in leaf extract of sweet potato (Ipomoea batatas). J. Med. Plants Res. 2012, 6, 2971-2976. [CrossRef]

35. Slimestad, R.; Fossen, T.; Verheul, M.J. The flavonoids of tomatoes. J. Agric. Food Chem. 2008, 56, $2436-2441$. [CrossRef] [PubMed]

36. Chitravathi, K.; Chauhan, O.P.; Raju, P.S. Shelf life extension of green chillies (Capsicum annuum L.) using shellac-based surface coating in combination with modified atmosphere packaging. J. Food Sci. Technol. 2016, 53, 3320-3328. [CrossRef] [PubMed]

37. Docimo, T.; Francese, G.; Ruggiero, A.; Batelli, G.; De Palma, M.; Bassolino, L.; Toppino, L.; Rotino, G.L.; Mennella, G.; Tucci, M. Phenylpropanoids accumulation in eggplant fruit: Characterization of biosynthetic genes and regulation by a MYB transcription factor. Front. Plant Sci. 2015, 6, 1233. [CrossRef] [PubMed]

38. Javaherdashti, M.; Ghasemnezhad, M.; Lahiji, H.S.; Shiri, M.A. Comparison of nutritional value and antioxidant compounds of some winter pumpkin (Cucurbita sp.) species fruits in Iran. Adv. Environ. Biol. 2012, 6, 2611-2616.

39. Winkel-Shirley, B. Flavonoid biosynthesis. A colorful model for genetics, biochemistry, cell biology, and biotechnology. Plant Physiol. 2001, 126, 485-493. [CrossRef] [PubMed]

40. Mertherns, F.; Kranz, H.; Bednarek, P.; Weisshaar, B. The Arabidopsis transcription factor MYB12 is a flavonol-specific regulator of phenylpropanoid biosynthesis. Plant Physiol. 2005, 138, 1083-1096.

41. Dixon, R.A.; Paiva, N.L. Stress-induced phenylpropanoid metabolism. Plant Cell 1995, 7, $1085-1097$. [CrossRef] [PubMed] 
42. Li, X.; Chen, L.; Hong, M.; Zhang, Y.; Zu, F.; Wen, J.; Yi, B.; Ma, C.; Shen, J.; Tu, J.; et al. A large insertion in bHLH transcription factor BrTT8 resulting in yellow seed coat in Brassica rapa. PLoS ONE 2012, 7, e44145. [CrossRef] [PubMed]

43. Qu, C.; Zhao, H.; Fu, F.; Wang, Z.; Zhang, K.; Zhou, Y.; Wang, X.; Wang, R.; Xu, X.; Tang, Z.; et al. Genome-wide survey of flavonoid biosynthesis genes and gene expression analysis between black- and yellow-seeded Brassica napus. Front. Plant Sci. 2016, 7, 1755. [CrossRef] [PubMed]

44. Masuzaki, S.; Shigyo, M.; Yamauchi, N. Complete assignment of structural genes involved in flavonoid biosynthesis influencing bulb color to individual chromosomes of the shallot (Allium cepa L.). Gene Genet. Syst. 2006, 81, 255-263. [CrossRef]

45. Kim, S.; Jones, R.; Yoo, K.S.; Pike, L.M. The L locus, one of complementary genes required for anthocyanin production in onions (Allium cepa), encodes anthocyanidin synthase. Theor. Appl. Genet. 2005, 111, 120-127. [CrossRef] [PubMed]

46. Schwinn, K.E.; Ngo, H.; Kenel, F.; Brummell, D.A.; Albert, N.W.; McCallum, J.A.; Pither-Joyce, M.; Crowhurst, R.N.; Eady, C.; Davies, K.M. The onion (Allium cepa L.) R2R3-MYB gene MYB1 regulates anthocyanin biosynthesis. Front. Plant Sci. 2016, 7, 1865. [CrossRef] [PubMed]

47. Kim, S.; Jones, R.; Yoo, K.S.; Pike, L.M. Gold color in onions (Allium cepa): A natural mutation of the chalcone isomerase gene resulting in a premature stop codon. Mol. Genet. Genom. 2004, 272, 411-419. [CrossRef] [PubMed]

48. Gonzali, S.; Mazzucato, A.; Perata, P. Purple as a tomato: Towards high anthocyanin tomatoes. Trends Plant Sci. 2009, 5, 237-241. [CrossRef] [PubMed]

49. Muir, S.R.; Collins, G.J.; Robinson, S.; Hughes, S.; Bovy, A.; Ric De Vos, C.H.; van Tunen, A.J.; Verhoeyen, M.E. Overexpression of petunia chalcone isomerase in tomato results in fruit containing increased levels of flavonols. Nat. Biotechnol. 2001, 19, 470-474. [CrossRef] [PubMed]

50. Dubos, C.; Stracke, R.; Grotewold, E.; Weisshaar, B.; Martin, C.; Lepiniec, L. MYB transcription factors in Arabidopsis. Trends Plant Sci. 2010, 15, 573-581. [CrossRef] [PubMed]

51. Giuliano, G. Provitamin A biofortification of crop plants: A gold rush with many miners. Curr. Opin. Biotechnol. 2017, 44, 169-180. [CrossRef] [PubMed]

52. Renna, M.; Serio, F.; Signore, A.; Santamaria, P. The yellow-purple Polignano carrot (Daucus carota L.): A multicolored landrace from the Puglia region (Southern Italy) at risk of genetic erosion. Genet. Resour. Crop Evol. 2014, 61, 1611-1619. [CrossRef]

53. Scarano, A.; Gerardi, C.; D'Amico, L.; Accogli, R.; Santino, A. Phytochemical analysis and antioxidant properties in colored Tiggiano carrots. Agriculture 2018, 8, 102. [CrossRef]

54. Yildiz, M.; Willis, D.K.; Cavagnaro, P.F.; Iorizzo, M.; Abak, K.; Simon, P.W. Expression and mapping of anthocyanin biosynthesis genes in carrot. Theor. Appl. Genet. 2013, 126, 1689-1702. [CrossRef] [PubMed]

55. Xu, Z.-S.; Huang, Y.; Wang, F.; Song, X.; Wang, G.-L.; Xiong, A.-S. Transcript profiling of structural genes involved in cyaniding-based anthocyanin biosynthesis between purple and non-purple carrot (Daucus carota L.) cultivars reveals distinct patterns. BMC Plant Biol. 2014, 14, 262. [CrossRef] [PubMed]

56. Xu, Z.-S.; Feng, K.; Que, F.; Wang, F.; Xiong, A.-S. A MYB transcription factor, DcMYB6, is involved in regulating anthocyanin biosynthesis in purple carrot taproots. Sci. Rep. 2017, 7, 45324. [CrossRef] [PubMed]

57. Cai, X.; Lin, L.; Wang, X.; Xu, C.; Wang, Q. Higher anthocyanin accumulation associated with higher transcription levels of anthocyanin biosynthesis genes in spinach. Genome 2018, 61, 487-496. [CrossRef] [PubMed]

58. Blanco, E.; Sabetta, W.; Danzi, D.; Negro, D.; Passeri, V.; De Lisi, A.; Paolocci, F.; Sonnante, G. Isolation and characterization of the flavonol regulator CCMYB12 from the globe artichoke [Cynara cardunculus var. scolymus (L.) Fiori]. Front. Plant Sci. 2018, 9, 941. [CrossRef] [PubMed]

59. Liu, Y.; Lin-Wang, K.; Espley, R.V.; Wang, L.; Yang, H.; Yu, B.; Dare, A.; Varkonyi-Gasic, E.; Wang, J.; Zhang, J.; et al. Functional diversification of the potato R2R3 MYB anthocyanin activators AN1, MYBA1, and MYB113 and their interaction with basic helix-loop-helix cofactors. J. Exp. Bot. 2016, 67, 2159-2176. [CrossRef] [PubMed]

60. D’Amelia, V.; Aversano, R.; Batelli, G.; Caruso, I.; Castellano, M.M.; Castro-Sanz, A.B.; Chiaiese, P.; Fasano, C.; Palomba, F.; Carputo, D. High AN1 variability and interaction with basic helix-loop-helix co-factors related to anthocyanin biosynthesis in potato leaves. Plant J. 2014, 80, 527-540. [CrossRef] [PubMed]

61. Li, W.; Wang, B.; Wang, M.; Yang, Q. Cloning and characterization of a potato StAN11 gene involved in anthocyanin biosynthesis regulation. J. Integr. Plant Biol. 2014, 56, 364-372. [CrossRef] [PubMed] 
62. D'Amelia, V.; Aversano, R.; Ruggiero, A.; Batelli, G.; Appelhagen, I.; Dinacci, C.; Hill, L.; Martin, C.; Carputo, D. Subfunctionalization of duplicate MYB genes in Solanum commersonii generated the cold-induced ScAN2 and the anthocyanin regulator ScAN1. Plant Cell Environ. 2018, 41, 1038-1051. [CrossRef] [PubMed]

63. Zhang, Y.; Butelli, E.; Alseekh, S.; Tohge, T.; Rallapalli, G.; Luo, J.; Kawar, P.G.; Hill, L.; Santino, A.; Fernie, A.R.; et al. Multi-level engineering facilitates the production of phenylpropanoid compounds in tomato. Nat. Commun. 2015, 6, 8635. [CrossRef] [PubMed]

64. Luo, J.; Butelli, E.; Hill, L.; Parr, A.; Niggeweg, R.; Bailey, P.; Weisshaar, B.; Martin, C. AtMYB12 regulates caffeoyl quinic acid and flavonol synthesis in tomato: Expression in fruit results in very high levels of both types of polyphenol. Plant J. 2008, 56, 316-326. [CrossRef] [PubMed]

65. Zhu, G.; Wang, S.; Huang, Z.; Zhang, S.; Liao, Q.; Zhang, C.; Lin, T.; Qin, M.; Yang, C.; Cao, X.; et al. Rewiring of the fruit metabolome in tomato breeding. Cell 2018, 172, 249-261. [CrossRef] [PubMed]

66. Mathews, H.; Clendennen, S.K.; Caldwell, C.G.; Liu, X.L.; Connors, K.; Matheis, N.; Schuster, D.K.; Menasco, D.J.; Wagoner, W.; Lightner, J.; et al. Activation tagging in tomato identifies a transcriptional regulator of anthocyanin biosynthesis, modification, and transport. Plant Cell 2003, 15, 1689-1703. [CrossRef] [PubMed]

67. Kiferle, C.; Fantini, E.; Bassolino, L.; Povero, G.; Spelt, C.; Buti, S.; Giuliano, G.; Quattrocchio, F.; Koes, R.; Perata, P.; et al. Tomato R2R3-MYB proteins SIANT1 and SIAN2: Same protein activity, different roles. PLoS ONE 2015, 10, e0136365. [CrossRef] [PubMed]

68. Gao, Y.; Liu, J.; Chen, Y.; Tang, H.; Wang, Y.; He, Y.; Ou, Y.; Sun, X.; Wang, S.; Yao, Y. Tomato SlAN11 regulates flavonoid biosynthesis and seed dormancy by interaction with bHLH proteins but not with MYB proteins. Hortic. Res. 2018, 5, 27. [CrossRef] [PubMed]

69. Zoratti, L.; Karppinen, K.; Luengo Escobar, L.; Häggman, H.; Jaakola, L. Light-controlled flavonoid biosynthesis in fruits. Front. Plant Sci. 2014, 5, 534. [CrossRef] [PubMed]

70. Jaakola, L. New insights into the regulation of anthocyanin biosynthesis in fruits. Trends Plant Sci. 2013, 18, 477-483. [CrossRef] [PubMed]

71. Castagna, A.; Dall'Asta, C.; Chiavaro, E.; Galaverna, G.; Ranieri, A. Effect of post-harvest UV-B irradiation on polyphenol profile and antioxidant activity in flesh and peel of tomato fruits. Food Bioprocess Technol. 2014, 7, 2241-2250. [CrossRef]

72. Zhang, J.; Satterfield, M.B.; Brodbelt, J.S.; Britz, S.J.; Clevidence, B.; Novotny, J.A. Structural characterization and detection of kale flavonoids by electrospray ionization mass spectrometry. Anal. Chem. 2003, 75, 6401-6407. [CrossRef] [PubMed]

73. Fallovo, C.; Schreiner, M.; Schwarz, D.; Colla, G.; Krumbein, A. Phytochemical changes induced by different nitrogen supply forms and radiation levels in two leafy Brassica species. J. Agric. Food Chem. 2011, 59, 4198-4207. [CrossRef] [PubMed]

74. Neugart, S.; Fiol, M.; Schreiner, M.; Rohn, S.; Zrenner, R.; Kroh, L.W.; Krumbein, A. Low and moderate photosynthetically active radiation affects the flavonol glycosides and hydroxycinnamic acid derivatives in kale (Brassica oleracea var. sabellica) dependent on two low temperatures. Plant Physiol. Biochem. 2013, 72, 161-168. [PubMed]

75. Ghasemzadeh, A.; Ashkani, S.; Baghdadi, A.; Pazoki, A.; Jaafar, H.Z.E.; Rahmat, A. Improvement in flavonoids and phenolic acids production and pharmaceutical quality of sweet basil (Ocimum basilicum $\mathrm{L}$.) by Ultraviolet-B Irradiation. Molecules 2016, 21, 1203. [CrossRef] [PubMed]

76. Tyagi, S.; Sahay, S.; Imran, M.; Rashmi, K.; Mahesh, S.S. Pre-harvest factors influencing the postharvest quality of fruits: A review. Curr. J. Appl. Sci. Technol. 2017, 23, 1-12. [CrossRef]

77. Schmidt, S.; Zietz, M.; Schreiner, M.; Rohn, S.; Kroh, L.W.; Krumbein, A. Genotypic and climatic influences on the concentration and composition of flavonoids in kale (Brassica oleracea var. sabellica). Food Chem. 2010, 119, 1293-1299. [CrossRef]

78. Deluc, L.; Quilici, D.R.; Decendit, A.; Grimplet, J.; Wheatley, M.D.; Schlauch, K.A.; Mérillon, J.-M.; Cushman, J.C.; Cramer, G.R. Water deficit alters differentially metabolic pathways affecting important flavor and quality traits in grape berries of Cabernet Sauvignon and Chardonnay. BMC Genom. 2009, 10, 212. [CrossRef] [PubMed]

79. Malejane, D.N.; Tinyani, P.; Soundy, P.; Sutanbawa, Y.; Sivakumar, D. Deficit irrigation improves phenolic content and antioxidant activity in leafy lettuce varieties. Food Sci. Nutr. 2018, 6, 334-341. [CrossRef] [PubMed] 
80. Min, O.H.; Carey, E.E.; Rajashekar, C.B. Regulated water deficits improve phytochemical concentration in lettuce. J. Am. Soc. Hortic. Sci. 2010, 135, 223-229.

81. Heimler, D.; Romani, A.; Ieri, F. Plant polyphenol content, soil fertilization and agricultural management: A review. Eur. Food Res. Technol. 2017, 243, 1107-1115. [CrossRef]

82. Nguyen, P.M.; Niemeyer, E.D. Effects of nitrogen fertilization on the phenolic composition and antioxidant properties of basil (Ocinum basilicum L.). J. Agric. Food Chem. 2008, 56, 8685-8691. [CrossRef] [PubMed]

83. Fortier, E.; Desjardins, Y.; Tremblay, N.; Bèlec, C.; Côtè, M. Influence of irrigation and nitrogen fertilization on broccoli polyphenolics concentration. Acta Hortic. 2010, 856, 55-62. [CrossRef]

84. Bénard, C.; Gutier, H.; Bourgaud, F.; Grasselly, F.; Navez, B.; Caris-Veurat, C.; Weiss, M.; Gènard, M. Effects of low nitrogen supply on tomato (Solanum lycopersicum) fruit yeld and quality with special emphasis on sugars, acids, ascorbate, carotenoids, and phenolic compounds. J. Agric. Food Chem. 2009, 57, 4112-4123. [CrossRef] [PubMed]

85. Valverde, J.; Reilly, K.; Villacreces, S.; Gaffney, M.; Grant, J.; Brunton, N. Variation in bioactive content in broccoli (Brassica oleracea var. italica) grown under conventional and organic production systems. J. Sci. Food Agric. 2014, 95, 1163-1171. [PubMed]

86. Kårlund, A.; Moor, U.; Sandell, M.; Karjalainen, R.O. The impact of harvesting, storage and processing factors on health-promoting phytochemicals in beriies and fruits. Processes 2014, 2, 596-624. [CrossRef]

87. Shoji, T. Polyphenols as natural food pigments: Changes during food processing. Am. J. Food Technol. 2007, 2, 570-581.

88. Papoulias, E.; Siomos, A.S.; Koukounaras, A.; Gerasopoulos, D.; Kazakis, E. Effects of genetic, pre- and post-harvest factors on phenolic content and antioxidant capacity of white asparagus spears. Int. J. Mol. Sci. 2009, 10, 5370-5380. [CrossRef] [PubMed]

89. Makris, D.; Rossiter, J.T. Domestic processing of onion bulbs (Allium cepa) and asparagus spears (Asparagus officinalis): Effect on flavonol content and antioxidant status. J. Agric. Food Chem. 2001, 49, 3216-3222. [CrossRef] [PubMed]

90. Miglio, C.; Chiavaro, E.; Visconti, A.; Fogliano, V.; Pellegrini, N. Effects of different cooking methods on nutritional and physicochemical characteristics of selected vegetables. J. Agric. Food Chem. 2008, 56, 139-147. [CrossRef] [PubMed]

91. Capanoglu, E.; Beekwilder, J.; Boyacioglu, D.; De Vos, R.C.H.; Hall, R.D. The effect of industrial food processing on potentially health-beneficial tomato antioxidants. Crit. Rev. Food Sci. Nutr. 2010, 50, 919-930. [CrossRef] [PubMed]

92. Ekezie, F.-G.C.; Sun, D.-W.; Cheng, J.-H. A review on recent advances in cold plasma technology for the food industry: Current applications and future trends. Trends Food Sci. Technol. 2017, 69, 46-58. [CrossRef]

93. Zhu, C.; Sanahuja, G.; Yuan, D.; Farré, G.; Arjó, G.; Berman, J.; Zorilla-López, U.; Banakar, R.; Bai, C.; Pérez-Massot, E.; et al. Biofortification of plants with altered antioxidant content and composition: Genetic engineering strategies. Plant Biotechnol. J. 2013, 11, 129-141. [CrossRef] [PubMed]

94. Raiola, A.; Rigano, M.M.; Calafiore, R.; Frusciante, L.; Barone, A. Enhancing the health-promoting effects of tomato fruit for biofortified food. Mediat. Inflamm. 2014, 2014, 139873. [CrossRef] [PubMed]

95. Povero, G.; Gonzali, S.; Bassolino, L.; Mazzucato, A.; Perata, P. Transcriptional analysis in high-anthocyanin tomatoes reveals synergistic effect of Aft and atv genes. J. Plant Physiol. 2011, 168, 270-279. [CrossRef] [PubMed]

96. He, Q.; Zhang, Z.; Zhang, L. Anthocyanin accumulation, antioxidant ability and stability, and a transcriptional analysis of anthocyanin biosynthesis in purple heading Chinese cabbage (Brassica rapa L. ssp. pekinensis). J. Agric. Food Chem. 2016, 64, 132-145. [CrossRef] [PubMed]

97. Li, X.; Pang, W.; Piao, Z. Omics meets phytonutrients in vegetable brassicas: For nutritional quality breeding. Hortic. Plant J. 2017, 3, 247-254. [CrossRef]

98. Odeny, D.A.; Nanina, S.S. Allium. In Wild Crop Relatives: Genomic and Breeding Resources Vegetables; Kole, C., Ed.; Springer: Berlin/Heildelberg, Germany, 2011. [CrossRef]

99. Lukaszewicz, M.; Matysiak-Kata, I.; Skala, J.; Fecka, I.; Cisowski, W.; Szopa, J. Antioxidant capacity manipulation in transgenic potato tuber by changes in phenolic compounds content. J. Agric. Food Chem. 2004, 52, 1526-1533. [CrossRef] [PubMed]

100. Wei, Q.; Wang, Q.-Y.; Feng, Z.-H.; Wang, B.; Zhang, Y.-F.; Yang, Q. Increased accumulation of anthocyanins in transgenic potato tubers by overexpressing the 3GT gene. Plant Biotechnol. Rep. 2012, 6, 69-75. [CrossRef] 
101. Aksamit-Stachursa, A.; Korobczak-Sosna, A.; Kulma, A.; Szopa, J. Glycosyltransferase efficiently controls phenylpropanoid pathway. BMC Biotechnol. 2008, 8, 25. [CrossRef]

102. Verhoeyen, M.E.; Bovy, A.; Collins, G.; Muir, S.; Robinson, S.; de Vos, C.H.R.; Colliver, S. Increasing antioxidant levels in tomatoes through modification of the flavonoid biosynthetic pathway. J. Exp. Bot. 2002, 53, 2099-2106. [CrossRef] [PubMed]

103. Bovy, A.; de Vos, R.; Kemper, M.; Schijlen, E.; Almenar Pertejo, M.; Muir, S.; Collins, G.; Robinson, S.; Verhoeyen, M.; Hughes, S.; et al. High-flavonol tomatoes resulting from heterologous expression of the maize transcription factor gene LC and C1. Plant Cell 2002, 14, 2509-2526. [CrossRef] [PubMed]

104. Davuluri, G.R.; van Tuinen, A.; Fraser, P.D.; Manfredonia, A.; Newman, R.; Burgess, D.; Brummell, D.A.; King, S.R.; Palys, J.; Uhlich, J.; et al. Fruit-specific RNAi-mediated suppression of DET1 enhances carotenoid and flavonoid content in tomatoes. Nat. Biotechnol. 2005, 23, 890-895. [CrossRef] [PubMed]

105. Zhang, Y.; Chu, G.; Hu, Z.; Gao, Q.; Cui, B.; Tian, S.; Wang, B.; Chen, G. Genetically engineered anthocyanin pathway for high health-promoting pigment production in eggplant. Mol. Breed. 2016, 36, 54. [CrossRef]

106. Butelli, E.; Titta, L.; Giorgio, M.; Mock, H.P.; Peterek, S.; Schijlen, E.G.; Hall, R.D.; Bovy, A.G.; Luo, J.; Martin, C. Enrichment of tomato fruit with health-promoting anthocyanins by expression of selected transcription factors. Nat. Biotechnol. 2008, 26, 1301-1308. [CrossRef] [PubMed]

107. Lim, W.; Li, J. Synergetic effect of the onion CHI gene on the PAP1 regulatory gene for enhancing the flavonoid profile of tomato skin. Sci. Rep. 2017, 7, 12377. [CrossRef] [PubMed]

108. Čermák, T.; Baltes, N.J.; Čegan, R.; Zhang, Y.; Voytas, D.F. High-frequency, precise modification of the tomato genome. Genome Biol. 2015, 16, 232. [CrossRef] [PubMed]

109. Karkute, S.G.; Singh, A.K.; Gupta, O.P.; Singh, P.M.; Singh, B. CRISPR/Cas9 mediated genome engineering for improvement of horticultural crops. Front. Plant Sci. 2017, 8, 1635. [CrossRef] [PubMed]

110. Vilela, A.; Cosme, F. Drink Red: Phenolic Composition of Red Fruit Juices and Their Sensorial Acceptance. Beverages 2016, 2, 29. [CrossRef]

111. Dagan-Wiener, A.; Nissim, I.; Ben Abu, N.; Borgonovo, G.; Bassoli, A.; Niv, M.Y. Bitter or not? BitterPredict, a tool for predicting taste from chemical structure. Sci. Rep. 2017, 7, 12074. [CrossRef] [PubMed]

112. Sun, B.; de Sà, M.; Leandro, C.; Caldeira, I.; Duarte, F.L.; Spranger, I. Reactivity of polymeric proanthocyanidins toward salivary proteins and their contribution to young red wine astrincency. J. Agric. Chem. 2013, 61, 939-946. [CrossRef] [PubMed]

113. He, M.; Tian, H.; Luo, X.; Qi, X.; Chen, X. Molecular progress in research on fruit astringency. Molecules 2016, 20, 1434. [CrossRef] [PubMed]

114. Bassolino, L.; Zhang, Y.; Schoonbeek, H.J.; Kiferle, C.; Perata, P.; Martin, C. Accumulation of anthocyanins in tomato skin extends shelf life. New Phytol. 2013, 200, 650-655. [CrossRef] [PubMed]

115. Zhang, Y.; Butelli, E.; De Stefano, R.; Schoonbeek, H.J.; Magusin, A.; Pagliarani, C.; Wellner, N.; Hill, L.; Orzaez, D.; Granell, A.; et al. Anthocyanins double the shelf life of tomatoes by delaying overripening and reducing susceptibility to gray mold. Curr. Biol. 2013, 23, 1094-1100. [CrossRef] [PubMed]

116. Xie, Y.; Yang, W.; Tang, F.; Chen, X.; Ren, L. Antibacterial activities of flavonoids: Structure-activity relationship and mechanism. Curr. Med. Chem. 2015, 22, 132-149. [CrossRef] [PubMed]

117. Rodriguez-Mateos, A.; Oruna-Concha, M.J.; Kwik-Uribe, C.; Vidal, A.; Spencer, J.P. Influence of sugar type on the bioavailability of cocoa flavanols. Br. J. Nutr. 2012, 108, 2243-2250. [CrossRef] [PubMed]

118. Murota, K.; Shimizu, S.; Chujo, J.H.; Moon, J.H.; Terao, J. Efficiency of absorption and metabolic conversion of quercetin and its glucosides in human intestinal cell line Caco-2. Arch. Biochem. Biophys. 2000, 384, 391-397. [CrossRef] [PubMed]

119. Murota, K.; Shimizu, S.; Miyamoto, S.; Izumi, T.; Obata, A.; Kikuchi, M.; Terao, J. Unique uptake and transport of isoflavone aglycones by human intestinal Caco-2 cells: Comparison of isoflavonoids and flavonoids. J. Nutr. 2002, 13, 1956-1961. [CrossRef] [PubMed]

120. Izumi, T.; Piskula, M.K.; Osawa, S.; Obata, A.; Tobe, K.; Saito, M.; Kataoka, S.; Kubota, Y.; Kikuchi, M. Soy isoflavone aglycones are absorbed faster and in higher ampounts than their glucosides in humans. J. Nutr. 2000, 130, 1695-1699. [CrossRef] [PubMed]

121. Walgren, R.A.; Kamaky, K.J.; Lindenmayer, G.E.; Walle, T. Efflux of dietary flavonoid quercetin $4^{\prime}$ - $\beta$-glucoside across human intestinal Caco-2 cell monolayers by apical multidrug resistance-associated protein-2. J. Pharmacol. Exp. Ther. 2000, 294, 830-836. [PubMed] 
122. Kobayashi, S.; Tanabe, S.; Sugiyama, M.; Konishi, Y. Transepitelial transport of hesperetin and hasperidin in intestinal Caco-2 cell monolayers. Biochim. Biophys. Acta 2008, 1778, 33-41. [CrossRef] [PubMed]

123. Santino, A.; Scarano, A.; De Santis, S.; De Benedictis, M.; Giovinazzo, G.; Chieppa, M. Gut microbiota modulation and anti-inflammatory properties of dietary polyphenols in IBD: New and consolidated perspectives. Curr. Pharm. Des. 2017, 23, 2344-2351. [CrossRef] [PubMed]

124. Cardona, F.; Andrés-Lacueva, C.; Tulipani, S.; Tinahones, F.J.; Queipo-Ortuño, M.I. Benefits of polyphenols on gut microbiota and implications in human health. J. Nutr. Biochem. 2013, 24, 1415-1422. [CrossRef] [PubMed]

125. Fragis, M.; Murayyan, A.I.; Neethirajan, S. Cytotoxic activity and anti-cancer potential of Ontario grown onion extracts against breast cancer cell lines. Funct. Foods Health Dis. 2018, 8, 159-174.

126. Charepalli, V.; Reddivari, L.; Radhakrishnan, S.; Vadde, R.; Agarwal, R.; Vanamala, JK. Anthocyanin-containing purple-fleshed potatoes suppress colon tumorigenesis via elimination of colon cancer stem cells. J. Nutr. Biochem. 2015, 26, 1641-1649. [CrossRef] [PubMed]

127. Lim, S.; Xu, J.; Kim, J.; Chen, T.-Y.; Su, X.; Standard, J.; Carey, E.; Griffin, J.; Herndon, B.; Katz, B.; et al. Role of anthocyanin-enriched purple-fleshed sweet potato p40 in colorectal cancer prevention. Mol. Nutr. Food Res. 2013, 57, 1908-1917. [CrossRef] [PubMed]

128. Kim, S.-H.; Jo, S.-H.; Kwon, Y.-I.; Hwang, J.-K. Effects of onion (Allium cepa L.) extract administration on intestinal $\alpha$-glucosidases activities and spikes in postprandial blood glucose levels in SD Rats model. Int. J. Mol. Sci. 2011, 12, 3757-3769. [CrossRef] [PubMed]

129. Fantini, N.; Colombo, G.; Riva, A.; Morazzoni, P.; Bombardelli, E.; Carai, M.A.M. Evidence of glycemia-lowering effect by a Cynara scolymus L. extract in normal and obese rats. Phytother. Res. 2011, 25, 43-46. [CrossRef] [PubMed]

130. Lin, D.; Xiao, M.; Zhao, J.; Li, Z.; Xing, B.; Li, X.; Kong, M.; Li, L.; Zhang, Q.; Liu, Y.; et al. An overview of plant phenolic compounds and their importance in human nutrition and management of type 2 diabetes. Molecules 2016, 21, 1374. [CrossRef] [PubMed]

131. Shinkafi, S.A.; Dauda, H. Antibacterial activity of Allium Cepa (Onion) on some pathogenic bacteria associated with ocular infections. Sch. J. Appl. Med. Sci. 2013, 1, 147-151.

132. Qadir, M.A.; Shahzadi, S.K.; Bashir, A.; Munir, A.; Shahzad, S. Evaluation of phenolic compounds and antioxidant and antimicrobial activities of some common herbs. Int. J. Anal. Chem. 2017, 2017, 3475738. [CrossRef] [PubMed]

133. Kumar, S.; Pandey, A.K. Chemistry and biological activities of flavonoids: An overview. Sci. World J. 2013, 2013, 162750. [CrossRef] [PubMed]

134. Romier, B.; Schneider, Y.J.; Larondelle, Y.; During, A. Dietary polyphenols can modulate the intestinal inflammatory response. Nutr. Rev. 2009, 67, 363-378. [CrossRef] [PubMed]

135. Tomlinson, M.L.; Butelli, E.; Martin, C.; Carding, S.R. Flavonoids from engineered tomatoes inhibit gut barrier pro-inflammatory cytokines and chemokines, via SAPK/JNK and p38 MAPK pathways. Front. Nutr. 2017, 4, 61. [CrossRef] [PubMed]

136. Scarano, A.; Butelli, E.; De Santis, S.; Cavalcanti, E.; Hill, L.; De Angelis, M.; Giovinazzo, G.; Chieppa, M.; Martin, C.; Santino, A. Combined dietary anthocyanins, flavonols, and stilbenoids alleviate inflammatory bowel disease symptoms in mice. Front. Nutr. 2018, 4, 75. [CrossRef] [PubMed]

137. Elberry, A.A.; Mufti, S.; Al-Maghrabi, J.; Sattar, E.A.; Ghareib, S.A.; Mosli, H.A.; Gabr, S.A. Immunomodulatory effect of red onion (Allium cepa Linn) scale extract on experimentally induces atypical prostatic hyperplasia in Wistar rats. Mediat. Inflamm. 2014, 2014, 640746. [CrossRef] [PubMed]

(C) 2018 by the authors. Licensee MDPI, Basel, Switzerland. This article is an open access article distributed under the terms and conditions of the Creative Commons Attribution (CC BY) license (http://creativecommons.org/licenses/by/4.0/). 